\title{
Fish Cholesterol 25-Hydroxylase Inhibits Virus Replication via Regulating Interferon Immune Response or Affecting Virus Entry
}

\author{
Ya Zhang ${ }^{1}$, Liqun Wang ${ }^{2,3}$, Xiaohong Huang ${ }^{1}$, Shaowen Wang ${ }^{1}$, Youhua Huang ${ }^{1 *}$ and \\ Qiwei Qin ${ }^{1,4 *}$

\begin{abstract}
${ }^{1}$ College of Marine Sciences, South China Agricultural University, Guangzhou, China, ${ }^{2}$ Key Laboratory of Tropical Marine Bio-resources and Ecology, South China Sea Institute of Oceanology, Chinese Academy of Sciences, Guangzhou, China, ${ }^{3}$ University of Chinese Academy of Sciences, Beijing, China, ${ }^{4}$ Laboratory for Marine Biology and Biotechnology, Qingdao National Laboratory for Marine Science and Technology, Qingdao, China
\end{abstract}

OPEN ACCESS

Edited by:

Stephanie DeWitte-Orr Wilfrid Laurier University, Canada

Reviewed by:

Alberto Cuesta,

University of Murcia, Spain

Nguyen T. Vo,

McMaster University, Canada

*Correspondence:

Youhua Huang

huangyh@scau.edu.cn

Qiwei Qin

qinqw@scau.edu.cn

Specialty section: This article was submitted to

Comparative Immunology,

a section of the journal

Frontiers in Immunology

Received: 01 December 2018

Accepted: 07 February 2019

Published: 06 March 2019

Citation:

Zhang Y, Wang L, Huang X, Wang S, Huang $Y$ and Qin Q (2019) Fish

Cholesterol 25-Hydroxylase Inhibits Virus Replication via Regulating Interferon Immune Response or Affecting Virus Entry.

Front. Immunol. 10:322. doi: 10.3389/fimmu.2019.00322
Cholesterol 25-hydroxylase $(\mathrm{CH} 25 \mathrm{H})$ is an interferon (IFN)-induced gene that catalyzes the oxidation of cholesterol to 25-hydroxycholesterol $(25 \mathrm{HC})$, which exerts broad-spectrum antiviral function. To investigate the roles of fish $\mathrm{CH} 25 \mathrm{H}$ in Singapore grouper iridovirus (SGIV) and red-spotted grouper nervous necrosis virus (RGNNV) infection, we cloned and characterized a $\mathrm{CH} 25 \mathrm{H}$ homolog from orange-spotted grouper (Epinephelus coioides) (EcCH25H). EcCH25H encoded a 271-amino-acid polypeptide, with 86 and 59\% homology with yellow croaker (Larimichthys crocea) and humans, respectively. $\mathrm{EcCH} 25 \mathrm{H}$ contained a conserved fatty acid (FA) hydroxylase domain and an ERG3 domain. EcCH25H expression was induced by RGNNV or SGIV infection, lipopolysaccharide (LPS) or poly (I:C) treatment in vitro. Subcellular localization showed that $\mathrm{EcCH} 25 \mathrm{H}$ and mutant $\mathrm{EcCH} 25 \mathrm{H}-\mathrm{M}$ were distributed in the cytoplasm and partly colocalized with the endoplasmic reticulum. SGIV and RGNNV replication was decreased by $\mathrm{EcCH} 25 \mathrm{H}$ overexpression, which was reflected in the reduced severity of the cytopathic effect and a decrease in viral gene transcription, but replication of both viruses was increased by knockdown of $\mathrm{EcCH} 25 \mathrm{H}$. Besides, the antiviral activity was dependent on its enzymatic activity. Treatment with $25 \mathrm{HC}$ significantly inhibited replication of SGIV and RGNNV. EcCH25H overexpression positively regulated the IFN-related molecules and proinflammatory cytokines, and increased both IFN and ISRE promoter activities. Moreover, $25 \mathrm{HC}$ treatment significantly suppressed SGIV and RGNNV entry into host cells. The similar inhibitory effect on SGIV entry was observed in $\mathrm{EcCH} 25 \mathrm{H}$ overexpression cells. Taken together, our findings demonstrated that EcCH25H inhibited SGIV and RGNNV infection by regulating IFN signaling molecules, and might also influence viral entry via an effect on cholesterol.

Keywords: cholesterol 25-hydroxylase, grouper, Singapore grouper iridovirus, red-spotted grouper nervous necrosis virus, viral replication, interferon-stimulated gene, viral entry 


\section{INTRODUCTION}

The innate immune response is the first line of defense against invading pathogens, by which numerous pattern recognition receptors (PRRs) recognize pathogens, triggering the promotion of the interferon (IFN)-mediated innate immune response and leading to transcription of numerous IFN-stimulated genes (ISGs) (1-3). It has been reported that ISGs exert antiviral effects by inhibiting specific stages in the life cycle of viruses (4). For example, IFN-induced transmembrane proteins (IFITMs) block viral entry $(5,6)$, and protein kinase $\mathrm{R}$ (PKR) inhibits translation of some viral proteins through the suppression of eukaryotic translation initiation factor (eIF)2a elongation factors (7), while viperin and tetherin inhibit virus release from host cells $(8,9)$. Cholesterol 25-hydroxylase $(\mathrm{CH} 25 \mathrm{H})$, an ISG $(10$, 11 ), is an endoplasmic reticulum (ER)-associated membrane protein that catalyzes the conversion of cholesterol to 25hydroxycholesterol $(25 \mathrm{HC})$ to reduce cholesterol accumulation $(12,13) .25 \mathrm{HC}$, a natural oxysterol, plays a role in regulating cholesterol homeostasis and sterol biosynthesis through the regulation of nuclear receptors and sterol response elementbinding proteins (SREBPs; in particular SREBP2) $(12,14,15)$. Recent reports have revealed that $25 \mathrm{HC}$ inhibits the replication of various enveloped viruses, including hepatitis $\mathrm{C}$ virus (HCV) $(16,17)$, porcine reproductive and respiratory syndrome virus (PRRSV) (18), murine cytomegalovirus (MCMV) (19), West Nile virus (20), pseudorabies virus (PRV) (21), herpes simplex virus 1 (22), as well as one non-enveloped virus (poliovirus) (23), but it is inactive against another non-enveloped virus (adenovirus) (19). Besides, increased evidence demonstrates that $25 \mathrm{HC}$ blocks the entry of some viruses, including vesicular stomatitis virus (VSV) (19), human immunodeficiency virus (HIV) (19) and PRRSV (24), by modifying membrane fusion between viruses and cells.

Groupers, Epinephelus spp., are important commercial fish species in China and Southeast Asian countries. In recent years, outbreaks of infections caused by Singapore grouper iridovirus (SGIV) and red spotted grouper nervous necrosis virus (RGNNV) have caused heavy economic losses in the grouper industry (25-27). SGIV, an enveloped double-stranded large DNA virus, was first isolated from diseased grouper (Epinephelus tauvina) and characterized as a novel member of the genus Ranavirus, family Iridoviridae $(26,28)$. The SGIV genome consists of $140,131 \mathrm{bp}$, encoding 162 open reading frames (ORFs) (29). RGNNV is a non-enveloped icosahedral RNA virus, belonging to the genus Betanodavirus, family Nodavirdae, which has been frequently isolated from grouper and European sea bass (Dicenthrarchus labrax). The RGNNV genome is composed of two single-stranded positive-sense RNAs (30); RNA1 (3.1 kb) encodes the RNA-dependent RNA-polymerase (RdRp), while RNA2 $(1.4 \mathrm{~kb})$ encodes the capsid protein (CP). In addition, RNA3, a subgenomic transcript of RNA1, contains one ORF that encodes two non-structural proteins (31).

In order to clarify the mode of action of grouper viruses, a large number of immune genes were cloned and their roles in grouper virus infection were studied. For example, some immune-related genes, such as ISG15 (32), mitochondrial antiviral signaling protein (MAVS) (33), and IFN regulatory factor (IRF) 3 (34) exhibited different antiviral activities against SGIV or RGNNV infection. Notably, the transcriptome analysis of virus-infected grouper spleen showed that several ISGs were regulated in response to SGIV (35), or RGNNV (36), while the roles of most ISGs in fish virus replication remained unclear.

In the present study, a $\mathrm{CH} 25 \mathrm{H}$ homolog from orangespotted grouper $(\mathrm{EcCH} 25 \mathrm{H})$ was cloned and characterized. We investigated the antiviral roles of $\mathrm{EcCH} 25 \mathrm{H}$ during the replication of SGIV and RGNNV. In addition, we found that $\mathrm{EcCH} 25 \mathrm{H}$ influenced the entry of SGIV and RGNNV. Our data will provide new insights into the function of fish $\mathrm{CH} 25 \mathrm{H}$ genes against infection by fish viruses.

\section{MATERIALS AND METHODS}

\section{Cells and Viruses}

Grouper spleen (GS) cells used in this study were grown in Leibovitz's L15 medium containing 10\% fetal bovine serum (FBS; Gibco) at $28^{\circ} \mathrm{C}$ (37). The virus stocks of SGIV and purified SGIV were propagated in GS cells, while the RGNNV stocks were propagated in grouper brain (GB) cells, and the titers of the viruses were determined in GS cells and GB cells, respectively, that were both grown in Leibovitz's L15 medium containing 10\% FBS $(32,38)$. Virus stocks were maintained at $-80^{\circ} \mathrm{C}$.

\section{Reagents}

25HC was purchased from Santa Cruz Biotechnology (sc214091), reconstituted in chloroform to a concentration of $12.4 \mathrm{mM}$, and stored at $-20^{\circ} \mathrm{C}$. Poly (I:C) and lipopolysaccharide (LPS) were purchased from Sigma-Aldrich. Poly (I:C) was reconstituted in RNase-free water at a concentration of $5 \mathrm{mg} / \mathrm{mL}$ and LPS was reconstituted in phosphate-buffer saline (PBS) at a concentration of $2.5 \mathrm{mg} / \mathrm{mL}$. The lipophilic dye $\mathrm{DiO}$ and amine-reactive Cy5 were purchased from Biotium.

\section{Cloning of EcCH25H and Sequence Analysis}

According to the expressed sequence tag (EST) sequences of $\mathrm{EcCH} 25 \mathrm{H}$ from the grouper spleen transcriptome (35), the fulllength $\mathrm{EcCH} 25 \mathrm{H}$ sequence was cloned using the primers listed in the Table 1 by PCR amplification. Sequence analysis of EcCH25H was carried out using the BLAST program (http://www.ncbi. nlm.nih.gov/blast), and the conserved domains were predicted using the SMART program (http://smart.embl-heidelberg.de/). Multiple amino-acid sequence alignments were performed using the ClustalX1.83 software and the data were edited using the GeneDoc program. The phylogenetic tree was carried out using the MEGA 6.0 software.

\section{Expression Patterns of EcCH25H in Innate Immunity}

To illustrate the expression changes of $\mathrm{EcCH} 25 \mathrm{H}$ in response to fish virus infection, GS cells were infected with SGIV or RGNNV at a multiplicity of infection (MOI) of 2.0, and harvested at $4,8,18,24,36 \mathrm{~h}$ post-infection (h.p.i.) for RNA extraction and quantitative real-time PCR (qPCR) analysis. To examine 
TABLE 1 | Primers used in this study.

\begin{tabular}{|c|c|}
\hline Primer names & Sequence $\left(5^{\prime}-3^{\prime}\right)$ \\
\hline EcCH25H-ORF-F & ATGAATGTGCTCTCCACAGAG \\
\hline $\mathrm{EcCH} 25 \mathrm{H}-\mathrm{ORF}-\mathrm{R}$ & CTCTGGTCGTAAATACTGTGCTGAT \\
\hline EcCH25H-C1-Ecorl-F & CCGGAATTCTATGAATGTGCTCTCCACAGAG \\
\hline EcCH25H-C1-BamHI-R & CGCGGATCCCTCTGGTCGTAAATACTGTGCTGAT \\
\hline $\mathrm{EcCH} 25 \mathrm{H}-\mathrm{M}-\mathrm{F}$ & $\begin{array}{l}\text { CAAGCCCAACAGTCTCTCCACAATGTCAACTA } \\
\text { CGCCCCCTAC }\end{array}$ \\
\hline EcCH25H-M-R & $\begin{array}{l}\text { GTGGAGAGACTGTTGGGCTTGGTGGCAGGGA } \\
\text { GCTCC }\end{array}$ \\
\hline siRNA1 & CCAGAGCAGAGAGAGATCCTGCTाT \\
\hline siRNA2 & ACCGCGCTGTTCACTTACTGAGAA \\
\hline SiRNA3 & GACAGCAGCTCACTGGAGCTGTTAT \\
\hline EcCH25H-RT-F & TCCACAGAGCATGTAGAGGG \\
\hline EcCH25H-RT-R & GTAGGACGCAGGCAGGTAA \\
\hline Actin-RT-F & TACGAGCTGCCTGACGGACA \\
\hline Actin-RT-R & GGCTGTGATCTCCTTCTGCA \\
\hline RGNNV CP-RT-F & CAACTGACAACGATCACACCTTC \\
\hline RGNNV CP-RT-R & CAATCGAACACTCCAGCGACA \\
\hline RGNNV RdRp-RT-F & GTGTCCGGAGAGGTTAAGGATG \\
\hline RGNNV RdRp-RT-R & CTTGAATTGATCAACGGTGAACA \\
\hline SGIV MCP-RT-F & GCA CGCTTCTCTCACCTTCA \\
\hline SGIV MCP-RT-R & AACGGCAACGGGAGCACTA \\
\hline SGIV VP19-RT-F & TCCAAGGGAGAAACTGTAAG \\
\hline SGIV VP19-RT-R & GGGGTAAGCGTGAAGAC \\
\hline EcIRF3-RT-F & GACAACAAGAACGACCCTGCTAA \\
\hline ECIRF3-RT-R & GGGAGTCCGCTTGAAGATAGACA \\
\hline ECIRF7-RT-F & CAACACCGGATACAACCAAG \\
\hline ECIRF7-RT-R & GTTCTCAACTGCTACATAGGG \\
\hline EcISG15-RT-F & CCTATGACATCAAAGCTGACGAGAC \\
\hline EcISG15-RT-R & GTGCTGTTGGCAGTGACGTTGTAGT \\
\hline EclFP35-RT-F & TTCAGATGAGGAGTTCTCTCTTGTG \\
\hline ECIFP35-RT-R & TCATATCGGTGCTCGTCTACTITCA \\
\hline EcMXI-RT-F & CGAAAGTACCGTGGACGAGAA \\
\hline EcMXI-RT-R & TGTTTGATCTGCTCCTTGACCAT \\
\hline EcMXII-RT-F & GCTTCATCAACTACAAGACCTTCGA \\
\hline EcMXII-RT-R & CGCCTTCCTAACAGTATCTCCTATTT \\
\hline EcTNF $\alpha-R T-F$ & GTGTCCTGCTGTTGCTTGGTA \\
\hline EcTNF $\alpha-R T-R$ & CAGTGTCCGACTTGATTAGTGCTT \\
\hline ECIL-6-RT-F & GGTTGGTCCAAGGTGTGCTTA \\
\hline EClL-6-RT-R & CTGGGATTGTCGAGGTCCTT \\
\hline EclL-8-RT-F & GCCGTCAGTGAAGGGAGTCTAG \\
\hline ECIL-8-RT-R & ATCGCAGTGGGAGTTGCA \\
\hline
\end{tabular}

the expression profiles of $\mathrm{EcCH} 25 \mathrm{H}$ in response to pathogenassociated molecular pattern (PAMP) molecules, GS cells were transfected with $200 \mathrm{ng}$ poly (I:C) or treated with $4 \mu \mathrm{g} / \mathrm{mL} \mathrm{LPS}$, and collected at 4, 8, 12, 24, $36 \mathrm{~h}$ for further qPCR analysis.

\section{Plasmid Construction and Cell Transfection}

To clarify the molecular function of $\mathrm{EcCH} 25 \mathrm{H}$ in vitro, the full-length wild-type $\mathrm{EcCH} 25 \mathrm{H}$ (aa 1-271) sequence was subcloned into pEGFP-C1 using the primers in Table 1.
Histidine codons $(\mathrm{H})$ at positions 239 and 240 of wild-type $\mathrm{EcCH} 25 \mathrm{H}$ (16) were converted to glutamine codons (Q) by sitedirected mutagenesis to create the mutant form $(\mathrm{EcCH} 25 \mathrm{H}$ M) lacking catalytic activity. The constructed plasmids (pEGFP$\mathrm{EcCH} 25 \mathrm{H}$ and $\mathrm{pEGFP}-\mathrm{EcCH} 25 \mathrm{H}-\mathrm{M}$ ) were subsequently verified by DNA sequencing.

Cell transfection was carried out using Lipofectamine 2000 reagent (Invitrogen). GS cells were seeded in 24-well plates at 60-70\% confluence for $18-24 \mathrm{~h}$, and cells were transfected with the mixture of $2 \mu \mathrm{L}$ Lipofectamine 2000 and $800 \mathrm{ng}$ plasmids and incubated for $6 \mathrm{~h}$. After replacing with fresh normal medium, cells were cultured at $28^{\circ} \mathrm{C}$ for further study.

\section{Subcellular Localization}

To determine the subcellular localization of $\mathrm{EcCH} 25 \mathrm{H}$, pEGFP-C1, pEGFP-EcCH25H, and pEGFP-EcCH25H-M were cotransfected with the pDsRed2-ER plasmid into GS cells as described above. At $48 \mathrm{~h}$ post-transfection, cells were fixed with $4 \%$ paraformaldehyde, and stained with 4,6-diamidino2-phenylindole (DAPI). Fluorescent images were observed by confocal laser scanning microscopy (CLSM).

\section{Virus Infection Assay}

To demonstrate the roles of $\mathrm{CH} 25 \mathrm{H}$ during virus infection, GS cells were manipulated using gene overexpression, RNA interference, or treatment with the product of $\mathrm{CH} 25 \mathrm{H}$, and then infected with fish viruses. In detail, GS cells that were transfected with pEGFP-C1, pEGFP-EcCH25H, or pEGFP-EcCH25H-M for $24 \mathrm{~h}$ were infected with SGIV or RGNNV at MOI 2.0. Cell morphology was observed and photographed using a phase contrast microscope; meanwhile, mock- and virus-infected cells were harvested at 24 h.p.i. for RNA extraction and qPCR analysis.

To knockdown the expression level of $\mathrm{EcCH} 25 \mathrm{H}$ in GS cells, three small interfering RNAs (siRNAs) targeting different sequences of EcCH25H mRNA were commercially synthesized by Invitrogen. GS cells were grown in 24 -well plates and then transfected with siRNAs (Table 1). The knockdown efficiency and transcription of viral genes were measured by qPCR.

In addition, the antiviral effects of metabolic product of $\mathrm{CH} 25 \mathrm{H}$, GS cells were treated with different concentrations of $25 \mathrm{HC}(1,2,4$, or $8 \mu \mathrm{M})$ and incubated for $72 \mathrm{~h}$. The cell viability was determined by 3-(4,5-dimethylthiazol-2-yl)2,5-diphenyltetrazolium bromide (MTT) assay. The whole-cell lysates of treated infected cells were collected at the indicated time points and virus titers were determined. GS cells were seeded in 96-well plates for $18-24 \mathrm{~h}$, and then infected with serial 10fold dilutions of SGIV samples in eight replicates. After 96144 h.p.i., the $50 \%$ tissue culture infective dose $\left(\mathrm{TCID}_{50}\right)$ assay was determined using the Reed-Muench method.

\section{Immunofluorescence Assay}

GS cells were pretreated with different concentrations of $25 \mathrm{HC}$ $(1,2$, or $4 \mu \mathrm{M})$ for $12 \mathrm{~h}$, and infected with RGNNV or SGIV at MOI 2.0. At 24 h.p.i., cells were fixed with $4 \%$ paraformaldehyde at $4{ }^{\circ} \mathrm{C}$ overnight, and permeabilized with PBS containing $0.2 \%$ Triton X-100 for $15 \mathrm{~min}$. After washing three times with PBS, the cells were blocked with $2 \%$ bovine serum albumin 
(BSA) (Sigma-Aldrich) for $30 \mathrm{~min}$, and incubated with primary antibodies (anti-CP serum 1:200) diluted in $0.2 \%$ BSA for $2 \mathrm{~h}$ at room temperature. The cells were washed three times with PBS, and incubated with the secondary antibody, fluorescence isothiocyanate-conjugated goat anti-rabbit IgG (1:200; Pierce) at room temperature. After $2 \mathrm{~h}$, cells were stained with 1 $\mathrm{mg} / \mathrm{mL}$ DAPI and observed under an inverted fluorescence microscope (Zeiss).

\section{Reporter Gene Assay}

To illustrate the activated patterns of IFN promotion by EcCH25H, luciferase plasmids including ISRE-Luc, IFN1-Luc and IFN3-Luc were used. GS cells were cotransfected with 150 ng ISRE-Luc, IFN1-Luc, and IFN3-Luc, and 400 or $800 \mathrm{ng}$ of either pEGFP-EcCH25H or pEGFP-C1. A total of $40 \mathrm{ng}$ SV40 was included to normalize luciferase activity. At $48 \mathrm{~h}$ post-transfection, cells were harvested to measure the luciferase activities using the Dual-Luciferase ${ }^{\circledR}$ Reporter Assay System (Promega), as described in the manufacturer's instructions.

\section{Virus Entry Assay}

Whether EcCH25H affected SGIV and RGNNV entry was investigated using two strategies, namely observation under CLSM and qPCR. On the one hand, GS cells were seeded in glass-bottom cell culture dishes and transfected with pEGFP$\mathrm{EcCH} 25 \mathrm{H}$ for $24 \mathrm{~h}$, or pretreated with $25 \mathrm{HC}$ for $12 \mathrm{~h}$. After the indicated times, the cells were prechilled at $4^{\circ} \mathrm{C}$ for $5 \mathrm{~min}$ and infected with Cy5-labeled SGIV at $4^{\circ} \mathrm{C}$ for $20 \mathrm{~min}$ in serum-free medium at $28^{\circ} \mathrm{C}$ for $1 \mathrm{~h}$. After being washed three times with medium, cells were fixed with $4 \%$ paraformaldehyde overnight and stained with the lipophilic dye $\mathrm{DiO}$ for $30 \mathrm{~min}$ (38). The cells were observed under CLSM and photographed. In each sample, 30 cells were selected for analysis and the data were represented as mean \pm SEM.

Given that highly purified RGNNV particles (about $25 \mathrm{~nm}$ in diameter) was difficult to be obtained for confocal microscopy, the effects of the $25 \mathrm{HC}$ on RGNNV entry were determined using qPCR. In brief, GS cells were pretreated with $25 \mathrm{HC}$ for $12 \mathrm{~h}$ and infected with RGNNV or SGIV in serum-free medium. After $1 \mathrm{~h}$, cells were washed three times with cold serum-free medium to remove unbound virus. Medium with $25 \mathrm{HC}$ was added and the cells were cultured for another $4 \mathrm{~h}$ (SGIV) or $1 \mathrm{~h}$ (RGNNV) at $28^{\circ} \mathrm{C}$. Cells were washed once with medium and treated with $0.2 \mathrm{~mL}$ citric acid buffer (citric acid $40 \mathrm{mM}$, potassium chloride $10 \mathrm{mM}$, sodium chloride $135 \mathrm{mM}, \mathrm{pH}$ 3.0) for $1 \mathrm{~min}$. Cells were harvested for RNA extraction and qPCR analysis to measure the amount of virus that had entered the cells (39).

\section{RNA Isolation and qPCR}

Total RNA was extracted and reversed using the ReverTra Ace qPCR RT Kit (TOYOBO) as described previously (32). qPCR was performed in a Roche 480 Real Time Detection System (Roche). Each assay was carried out under the following cycling conditions: $95^{\circ} \mathrm{C}$ for $5 \mathrm{~min}$ for activation, followed by 45 cycles at $95^{\circ} \mathrm{C}$ for $5 \mathrm{~s}, 60^{\circ} \mathrm{C}$ for $10 \mathrm{~s}$ and $72^{\circ} \mathrm{C}$ for $15 \mathrm{~s}$. The primers are listed in Table 1. The expression level of target genes normalized to $\beta$-actin was calculated with the $2^{-\Delta \Delta \mathrm{CT}}$ method. The data were indicated as mean \pm SD and were shown from one representative experiment carried out in triplicate. Statistics were carried out using SPSS version 20 (IBM, Armonk, NY, USA) by one-way ANOVA. Differences were considered statistically significant when $P$ was $<0.05$.

\section{RESULTS}

\section{Sequence Characterization of EcCH25H}

On the basis of the EST sequences from grouper spleen transcriptome, the full-length ORF of $\mathrm{EcCH} 25 \mathrm{H}$ was obtained by PCR. EcCH25H encoded a 271-amino-acid polypeptide that shared $86 \%$ and $59 \%$ identity with the yellow croaker, Larimichthys crocea (KKF33056.1) and human, Homo sapiens (NP_003947.1), respectively. Amino acid (aa) alignment analysis indicated that EcCH25H contained two conserved domains: ERG3 (aa 113-264) and fatty acid (FA) hydroxylase (aa 127260) (Figure 1A). Phylogenetic analysis revealed that $\mathrm{EcCH} 25 \mathrm{H}$ showed the closest relationship to that of $L$. crocea. All the $\mathrm{CH} 25 \mathrm{Hs}$ from different fish species were clustered into one group that was separated from the other groups, including birds, reptiles, mammals, and insects (Figure 1B).

\section{Expression Profiles of $\mathrm{EcCH} 25 \mathrm{H}$ in vitro}

To assess the changes in expression of $\mathrm{EcCH} 25 \mathrm{H}$ in challenged GS cells, the transcription level of $\mathrm{EcCH} 25 \mathrm{H}$ was examined by qPCR after infection with RGNNV or SGIV, or treatment with poly (I:C) or LPS. As demonstrated in Figure 2A, EcCH25H transcription level increased gradually and reached a peak at up to 72-fold higher than of the mock-infected control cells at $36 \mathrm{~h}$ during RGNNV infection. During infection with SGIV, $\mathrm{EcCH} 25 \mathrm{H}$ transcription level was up-regulated between 18 and 24 h.p.i., reaching 216 -fold higher than the level attained in the mock-infected cells, before decreasing at 36 h.p.i. (Figure 2B). After transfection with poly (I:C), EcCH25H expression level was induced gradually and reached a peak of 4.3 -fold at $24 \mathrm{~h}$ compared to the controls (Figure 2C), while EcCH25H mRNA levels could also be induced by LPS (Figure 2D). Thus, $\mathrm{EcCH} 25 \mathrm{H}$ is induced in response to poly (I:C), LPS or fish virus infection.

\section{Subcellular Localization of EcCH25H}

$\mathrm{CH} 25 \mathrm{H}$ is an ER-associated hydroxylase that catalyzes the conversion of cholesterol to $25 \mathrm{HC}$, and $\mathrm{CH} 25 \mathrm{H}$ contains tripartite histidine residues, which are critical for their hydroxylase activities (40). To explore whether $\mathrm{EcCH} 25 \mathrm{H}$ was colocalized with ER in vitro and whether its localization was dependent on hydroxylase activity, EcCH25H-M was generated by converting histidine codons at positions 239 and 240 to glutamines, using site-directed mutagenesis. For subcellular localization analysis, pEGFP-C1, pEGFP$\mathrm{EcCH} 25 \mathrm{H}$, or pEGFP-EcCH25H-M, was cotransfected with pDsRed2-ER plasmid into GS cells. The green fluorescence in pEGFP-C1-transfected cells was distributed throughout the cytoplasm and nucleus (Figure 3). However, in pEGFPEcCH25H- and pEGFP-EcCH25H-M-transfected cells, the green fluorescence was distributed in the cytoplasm in two forms: point-like uniform and dot-like aggregation forms, 
A

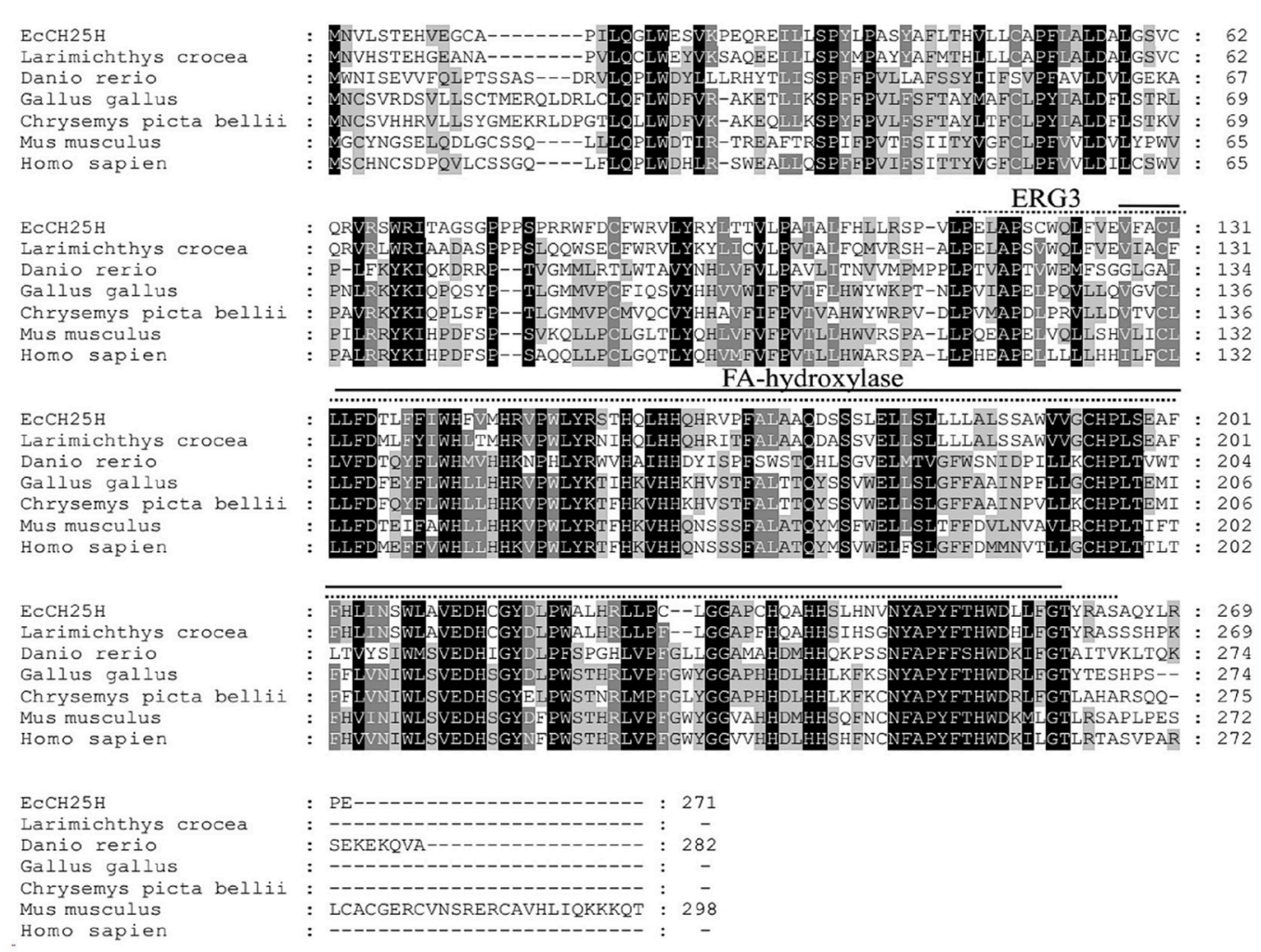

B

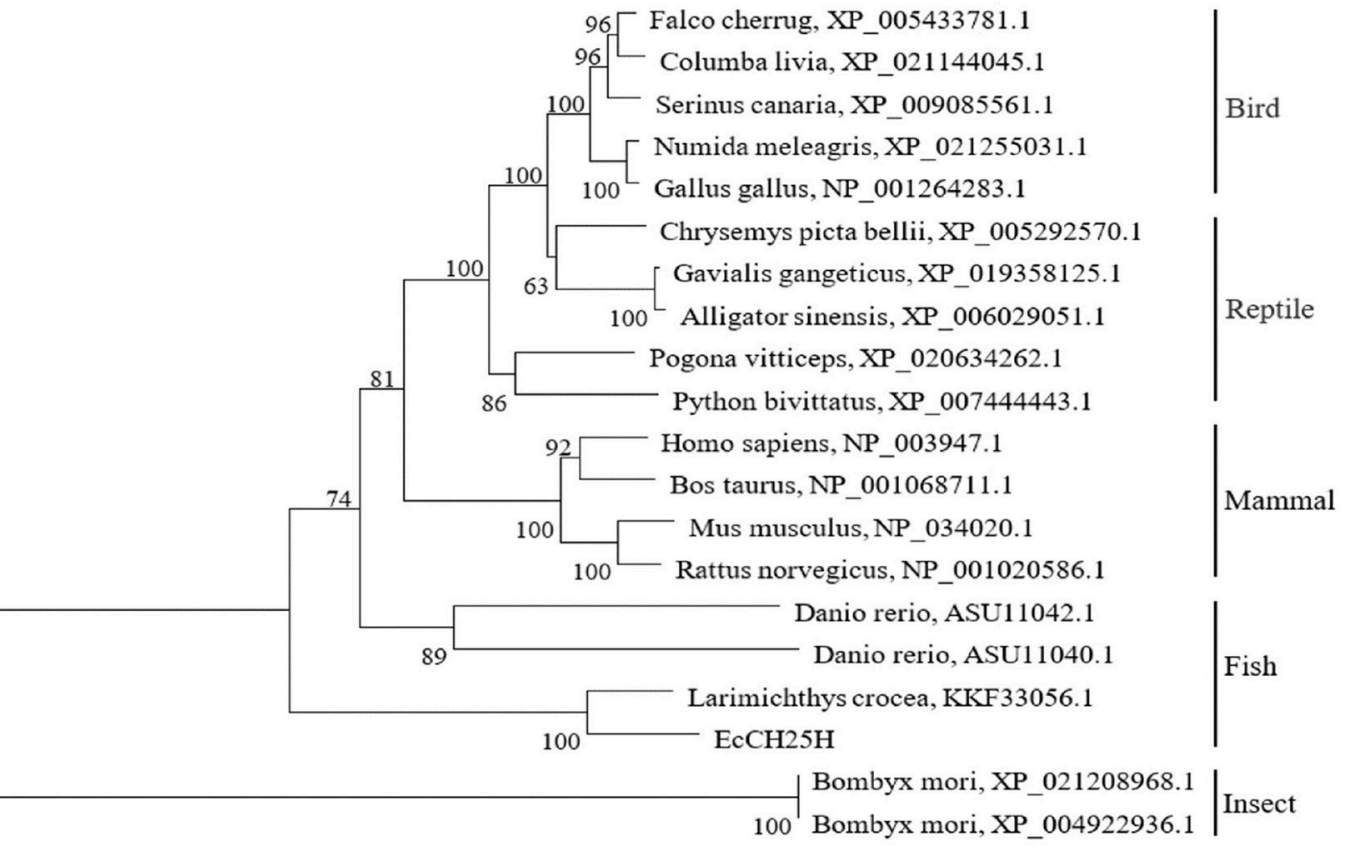

0.2

FIGURE 1 | Analysis of $\mathrm{CH} 25 \mathrm{H}$ proteins. (A) Amino acid alignment of $\mathrm{CH} 25 \mathrm{Hs}$ from different species. The ERG3 and FA-hydroxylase domains are represented by straight and dotted lines, respectively. Accession numbers were: Larimichthys crocea, KKF33056.1; Danio rerio, ASU11040.1; Gallus gallus, NP_001264283.1; Chrysemys picta bellii, XP_005292570.1; Mus musculus, NP_034020.1; Homo sapiens, NP_003947.1. (B) Phylogenetic analysis of CH25Hs. A neighbor-joining tree was constructed based on the protein sequences of $\mathrm{CH} 25 \mathrm{H}$-like genes from different species using MEGA 6.0 software. Numbers at the nodes denote the bootstrap values of 1,000 replicates. Scale represents the numbers of substitutions per 1,000 bases. 
A

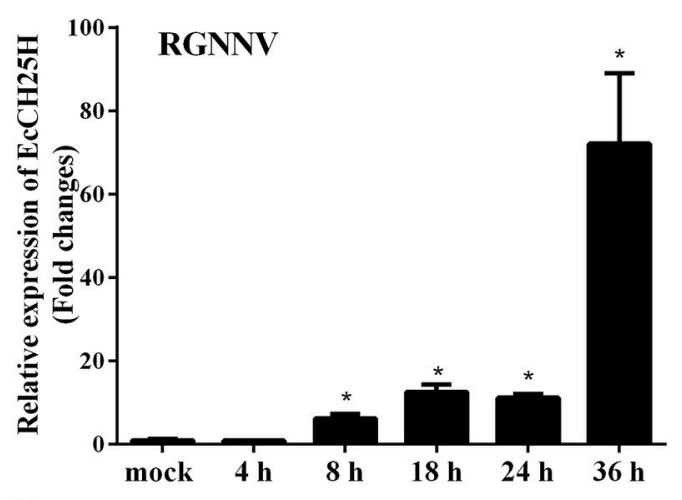

C

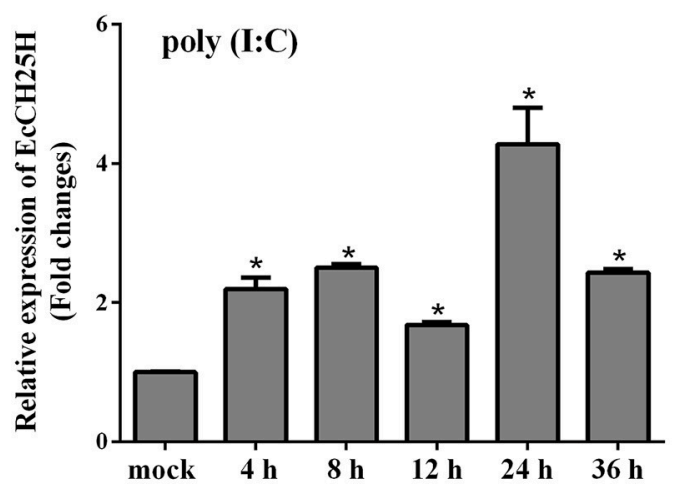

B

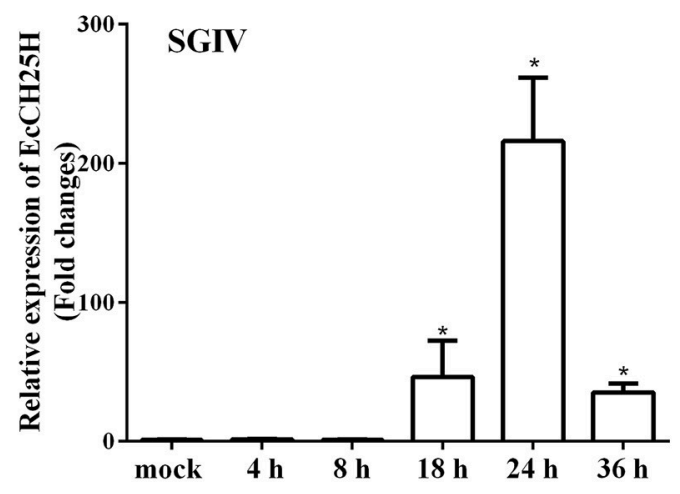

D

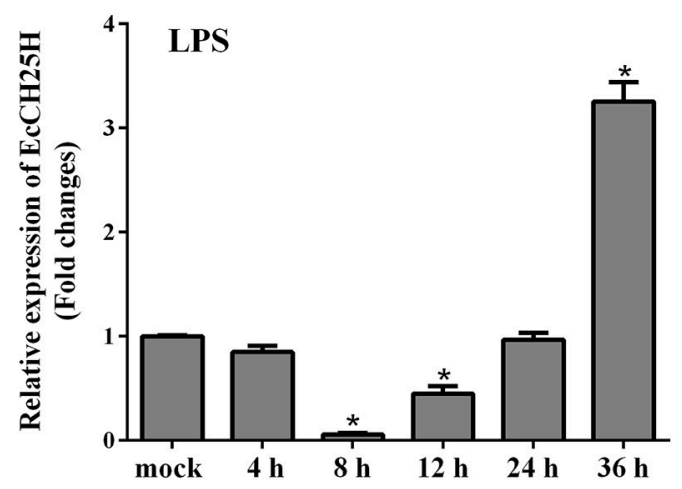

FIGURE 2 | Expression patterns of EcCH25H in vitro. GS cells were seeded in 24-well plates overnight, then infected with RGNNV (A) or SGIV (B) at MOI 2 , transfected with $200 \mathrm{ng}$ poly (I:C) (C) or pre-treated with $4 \mu \mathrm{g} / \mathrm{mL}$ LPS (D) for $36 \mathrm{~h}$. At the indicated time points, GS cells were sampled to detect the expression levels of $\mathrm{EcCH} 25 \mathrm{H}$ by $\mathrm{qPCR}(n=3$, means $\pm \mathrm{SD}) .{ }^{*} P<0.05$.

which were both colocalized partly with the red fluorescence of the ER. Therefore, we suggest that EcCH25H encoded an ER-localized protein, and that its localization was independent of hydroxylase activity.

\section{Antiviral Effects of EcCH25H on Fish Virus Replication in vitro}

To explore the effects of $\mathrm{EcCH} 25 \mathrm{H}$ overexpression on fish virus replication and whether it depends on the enzymatic activity of $\mathrm{CH} 25 \mathrm{H}$, GS cells were transfected with pEGFPC1, pEGFP-EcCH25H, or pEGFP-EcCH25H-M for $24 \mathrm{~h}$, and then infected with SGIV or RGNNV for a further $24 \mathrm{~h}$. The transcription level of $\mathrm{EcCH} 25 \mathrm{H}$ was examined by qPCR to confirm the successful ectopic expression of EcCH25H and $\mathrm{EcCH} 25 \mathrm{H}-\mathrm{M}$ in transfected cells. mRNA expression of $\mathrm{EcCH} 25 \mathrm{H}$ and $\mathrm{EcCH} 25 \mathrm{H}-\mathrm{M}$ was significantly increased up to 1,322.2- and 1,235.7-fold compared with that of the control vector cells (Figure 4A). Compared to the control vector cells, the cytopathic effect (CPE) induced by SGIV and RGNNV was weakened in $\mathrm{EcCH} 25 \mathrm{H}$-overexpressing cells. In contrast, $\mathrm{CPE}$ severity was significantly increased in EcCH25H-Moverexpressing cells compared with EcCH25H-overexpressing cells (Figure 4B). Consistently, the transcription levels of the SGIV major capsid protein (MCP) and VP19 genes, as well as RGNNV CP and RdRp genes, were significantly inhibited when $\mathrm{EcCH} 25 \mathrm{H}$ was overexpressed. However, the mutant significantly decreased the inhibitory effects of $\mathrm{EcCH} 25 \mathrm{H}$ on viral gene transcriptions (Figures 4C,D). Thus, the results demonstrated that $\mathrm{EcCH} 25 \mathrm{H}$ overexpression inhibited replication of RGNNV and SGIV, and that the antiviral effects were dependent on its enzymatic activity.

To further investigate whether knockdown of $\mathrm{EcCH} 25 \mathrm{H}$ promoted SGIV and RGNNV replication, we designed three siRNAs targeting $\mathrm{EcCH} 25 \mathrm{H}$, and examined interference efficiency in GS cells using qPCR. Compared with the negative control siRNA, siRNA1 decreased expression of EcCH25H, with 47\% knockdown efficiency (Figure 5A). After transfection with siRNA-EcCH25H for $24 \mathrm{~h}$, GS cells were infected with SGIV and RGNNV for a further $24 \mathrm{~h}$, and collected to examine the transcription of viral genes by qPCR. Knockdown of EcCH25H by siRNA promoted SGIV and RGNNV replication compared with the cells transfected with the negative control siRNA (Figures 5B,C). Thus, it was proposed that $\mathrm{EcCH} 25 \mathrm{H}$ exerted the antiviral effects on SGIV and RGNNV infection. 


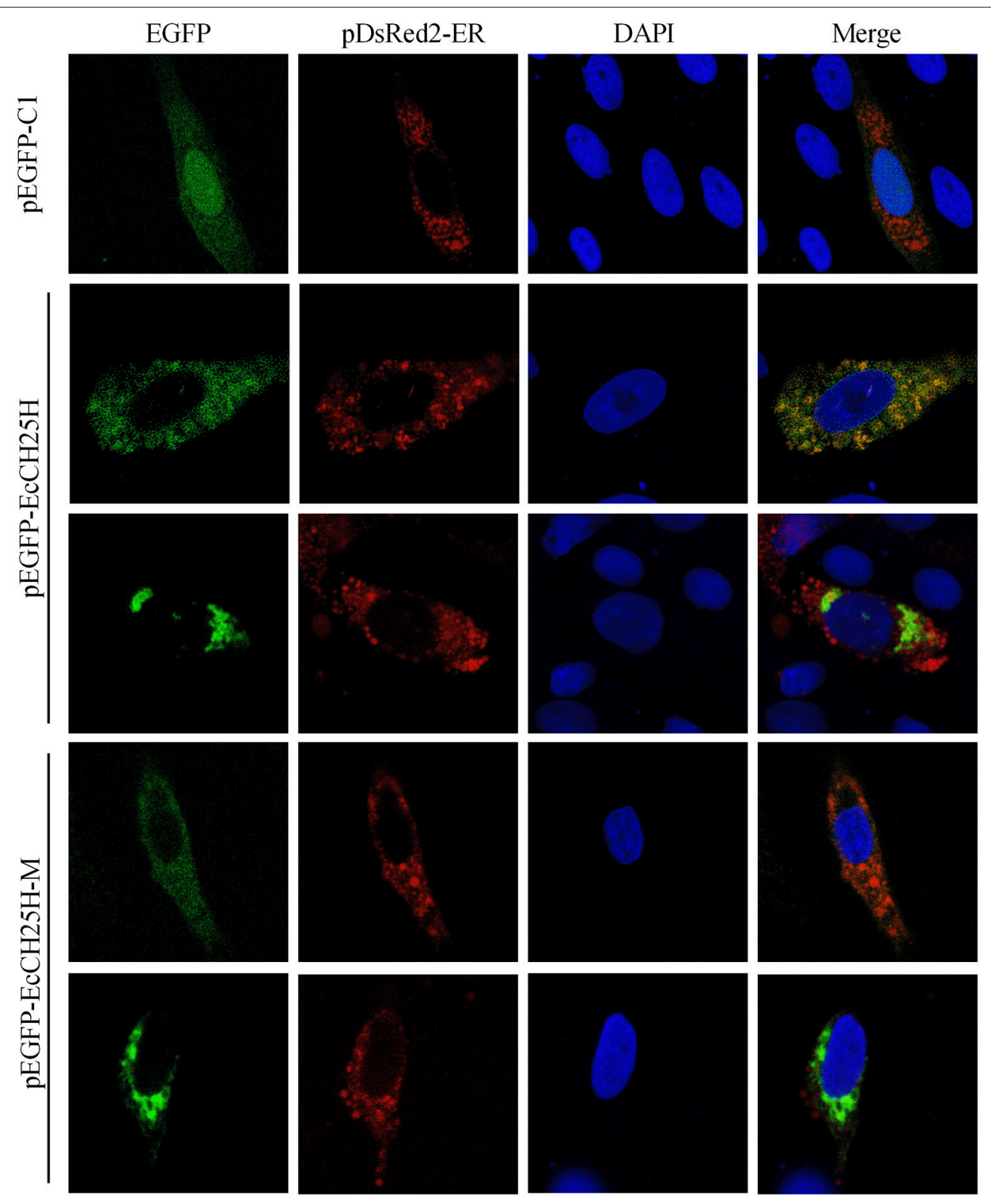

FIGURE 3 | Subcellular localization of EcCH25H in GS cells. PEGFP-C1, pEGFP-EcCH25H, or pEGFP-EcCH25H-M were co-transfected with pDsRed2-ER plasmid into GS cells for $48 \mathrm{~h}$, and stained with DAPI. Samples were observed under CLSM.

It has been reported that $\mathrm{CH} 25 \mathrm{H}$ exerts antiviral activities by producing $25 \mathrm{HC}(18,19,41)$. To explore whether $25 \mathrm{HC}$ plays a role in SGIV or RGNNV infection, GS cells were pretreated with different concentrations of $25 \mathrm{HC}$ for $12 \mathrm{~h}$, then infected with SGIV or RGNNV for $24 \mathrm{~h}$. Cell viability was not decreased when cells were exposed to $4 \mu \mathrm{M} 25 \mathrm{HC}$ for $72 \mathrm{~h}$ (Figure 6A). Virus titer assay indicated that 25HC significantly inhibited SGIV replication (Figure 6B). 25HC significantly inhibited expression of the CP protein of RGNNV in a dose-dependent manner (Figure 6C). 25HC significantly decreased the transcriptional level of MCP and VP19 of SGIV and CP and RdRp of RGNNV compared with chloroform (Figures 6D,E). Taken together, these results suggested that $\mathrm{EcCH} 25 \mathrm{H}$ exhibited antiviral activity by producing $25 \mathrm{HC}$, with the virus inhibition being dependent on the $\mathrm{EcCH} 25 \mathrm{H}$ enzymatic activity.

\section{EcCH25H Overexpression Positively Regulates the IFN Immune and Inflammatory Response}

To clarify the effects of EcCH25H on host IFN immune and inflammatory response, we examined expression of IFN signaling molecules, and proinflammatory cytokines by $\mathrm{QPCR}$ and the promoter activities of IFN-1, IFN-3 and ISRE in EcCH25H- and 
A
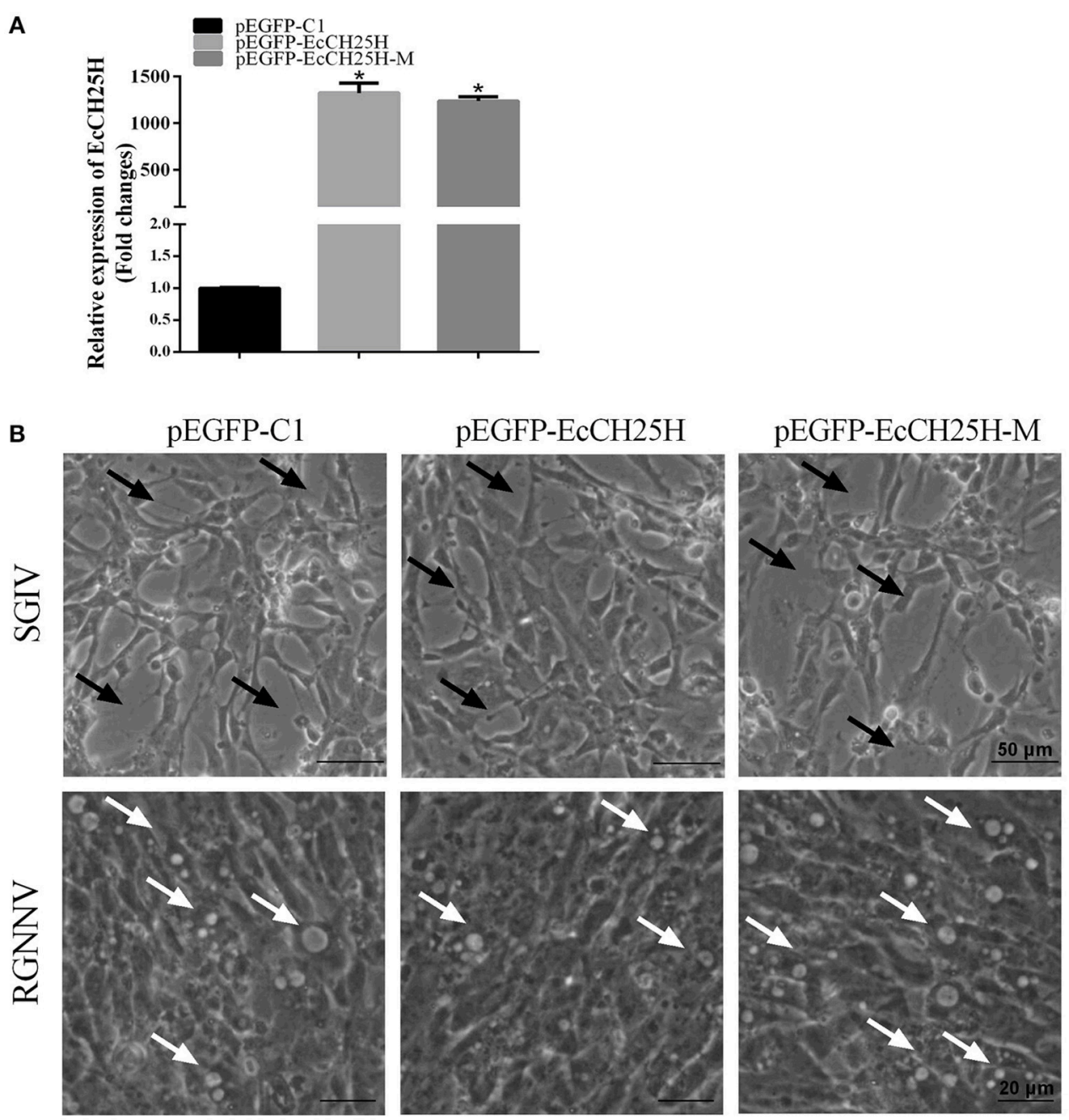

C

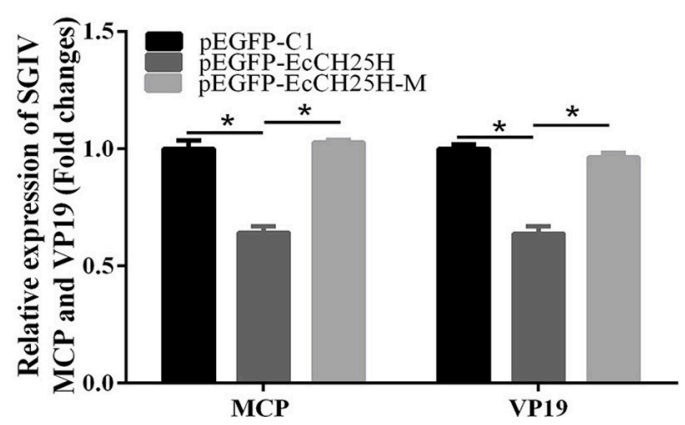

D

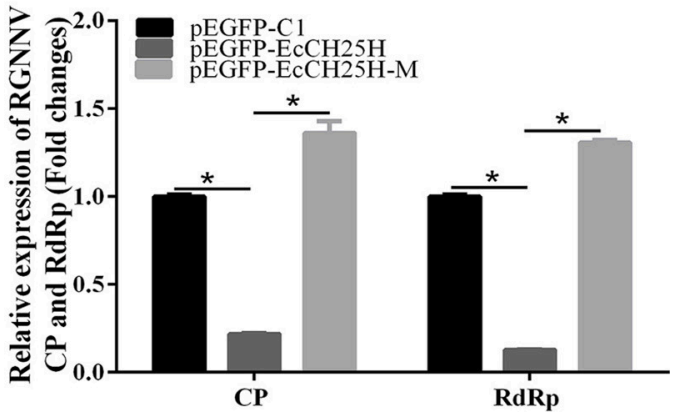

FIGURE 4 | Overexpression of EcCH25H significantly inhibited SGIV and RGNNV replication. (A) Transcription of EcCH25H in EcCH25H- and EcCH25H-M-overexpressing cells. GS cells were transfected with pEGFP-EcCH25H or pEGFP-EcCH25H-M, respectively, and were collected to detect the transcription level of $\mathrm{EcCH} 25 \mathrm{H}$ by qPCR at $48 \mathrm{~h}$ post-transfection. The primers $\mathrm{EcCH} 25 \mathrm{H}-\mathrm{RT}-\mathrm{F} / \mathrm{R}$ were designed to detect expression of $\mathrm{EcCH} 25 \mathrm{H}$ and $\mathrm{EcCH} 25 \mathrm{H}-\mathrm{M}$. (B) EcCH25H overexpression weakened the severity of CPE induced by RGNNV and SGIV in GS cells. GS cells were transfected with pEGFP-C1, pEGFP-EcCH25H, or pEGFP-EcCH25H-M for $24 \mathrm{~h}$, and infected with SGIV or RGNNV, respectively. At $24 \mathrm{~h}$.p.i., GS cells were observed for CPE using microscopy. In SGIV-infected cells, the black arrows indicated the severity of CPE induced by SGIV infection, which was characterized by cell rounding and aggregation of cells. The white arrows showed that vacuoles were induced by RGNNV infection. (C,D) Viral gene transcription of SGIV or RGNNV in EcCH25H- or EcCH25H-M-overexpressing cells. EcCH25H- and EcCH25H-M-overexpressing cells were infected with RGNNV or SGIV, and collected at 24 h.p.i. to determine by qPCR expression of MCP and VP19 of SGIV and CP and RdRp of RGNNV ( $n=3$, means \pm SD). ${ }^{*} P<0.05$. 


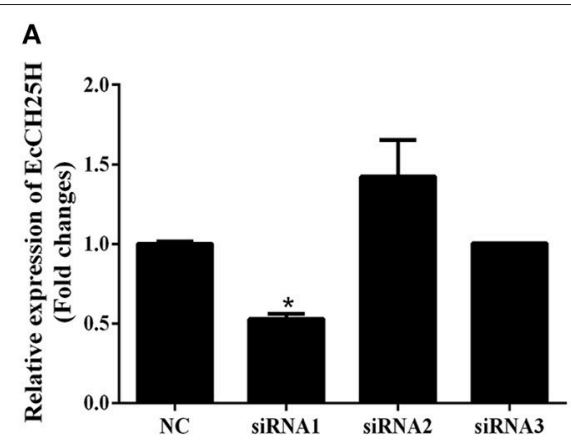

B

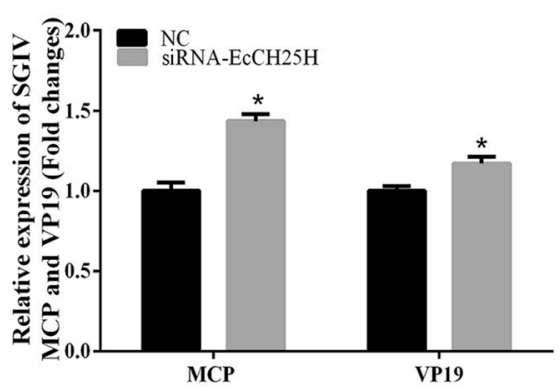

C

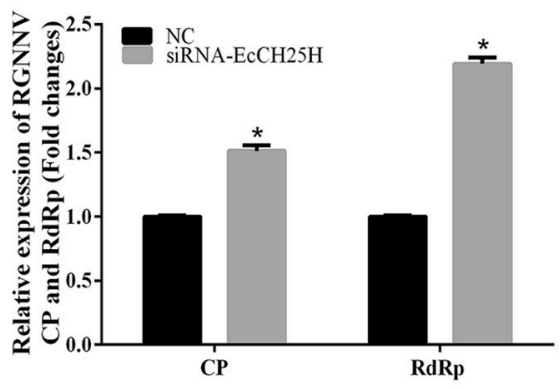

FIGURE 5 | Knockdown of EcCH25H by siRNA promoted SGIV and RGNNV replication in vitro. (A) GS cells were transfected with siRNAs targeting EcCH25H or negative control siRNA (NC). At 48 host-transfection, the $\mathrm{CH} 25 \mathrm{H}$ mRNA levels were determined by qPCR. (B,C) Viral gene transcription of SGIV or RGNNV in siRNA-EcCH25H- and negative control siRNA (NC)-overexpressing cells. $\mathrm{CH} 25 \mathrm{H}$ knockdown and control cells were infected with SGIV (B) or RGNNV (C) at $24 \mathrm{~h}$, and were collected at 24 h.p.i. to determine expression of MCP and VP19 of SGIV and CP and RdRp of RGNNV ( $n=3$, means \pm SD). ${ }^{*} P<0.05$.

EcCH25H-M-overexpressing cells. Compared with the controls, overexpression of $\mathrm{EcCH} 25 \mathrm{H}$ significantly increased expression of several IFN-related genes, including IRF3, IRF7, ISG15, IFNinduced $35-\mathrm{kDa}$ protein (IFP35), myxovirus resistance gene (MX)I and MXII. In EcCH25H-M-overexpressing cells, the concentration of mRNA transcripts was significantly lower than that in $\mathrm{EcCH} 25 \mathrm{H}$ overexpressing cells (Figure 7A). Reporter gene analysis showed that $\mathrm{EcCH} 25 \mathrm{H}$ overexpression significantly increased the luciferase activity of ISRE, IFN1, and IFN3 promoters in a dose-dependent manner (Figure 7B). We propose that $\mathrm{EcCH} 25 \mathrm{H}$ positively regulated IFN immune response.

The effects of $\mathrm{EcCH} 25 \mathrm{H}$ overexpression on expression of proinflammatory cytokines were also examined. mRNA production by tumor necrosis factor (TNF)- $\alpha$, interleukin (IL)6 and IL-8 genes was significantly increased in $\mathrm{EcCH} 25 \mathrm{H}-$ overexpressing cells compared with control cells, with the stimulatory effects of $\mathrm{EcCH} 25 \mathrm{H}$ being dependent on enzymatic activity (Figure 7C). Ectopic expression of EcCH25H in vitro upregulated the expression of IFN and the inflammatory response, and was related to enzyme activity.

\section{EcCH25H Inhibits SGIV and RGNNV Entry}

To further investigate whether $\mathrm{EcCH} 25 \mathrm{H}$ suppressed SGIV or RGNNV entry, GS cells were transfected with pEGFP-EcCH25H or pretreated with $25 \mathrm{HC}$ at $4 \mu \mathrm{M}$ for $12 \mathrm{~h}$, then infected with RGNNV or Cy5-labeled SGIV. EcCH25H overexpression reduced the number of red-fluorescence-labeled SGIV particles in the cytoplasm to $29.7 \%$ of that in empty-vector-transfected cells (Figures 8A,B). Furthermore, SGIV entry into GS cells pretreated with $25 \mathrm{HC}$ was significantly reduced to $48 \%$ of that in cells treated with chloroform (Figures 8C,D). 25HC decreased the transcriptional level of MCP of SGIV and CP of RGNNV compared with that achieved in cells exposed to chloroform (Figures 8E,F). These results suggested that $\mathrm{EcCH} 25 \mathrm{H}$ and $25 \mathrm{HC}$ might influence the entry of SGIV or RGNNV, by reducing the infectivity of virus particles in the cytoplasm.

\section{DISCUSSION}

An increasing number of studies have shown that $\mathrm{CH} 25 \mathrm{H}$ can inhibit various enveloped and non-enveloped viruses by production of $25 \mathrm{HC}(18,23,39)$. However, few have focused on the function of $\mathrm{CH} 25 \mathrm{H}$ in lower vertebrates. Here, we cloned and characterized $\mathrm{EcCH} 25 \mathrm{H}$ and analyzed its enzymatic product $25 \mathrm{HC}$ as antiviral restriction factors against iridovirus and nodavirus.

Based on bioinformatics analysis, we found that $\mathrm{EcCH} 25 \mathrm{H}$ from E. coioides shared $86 \%$ identity to that from $L$. crocea. Amino acid alignment analysis has shown that $\mathrm{EcCH} 25 \mathrm{H}$ contains the characteristic FA hydroxylase domain, which is similar to that of the zebrafish $\mathrm{CH} 25 \mathrm{H}$ (42), suggesting that $\mathrm{CH} 25 \mathrm{H}$ is conserved from lower vertebrates to mammals. Using qPCR analysis, our data showed that the concentration of EcCH25H increased significantly during SGIV and RGNNV infection, a finding which was consistent with the previous studies in which $\mathrm{CH} 25 \mathrm{H}$ was induced in response to VSV (19), 
A

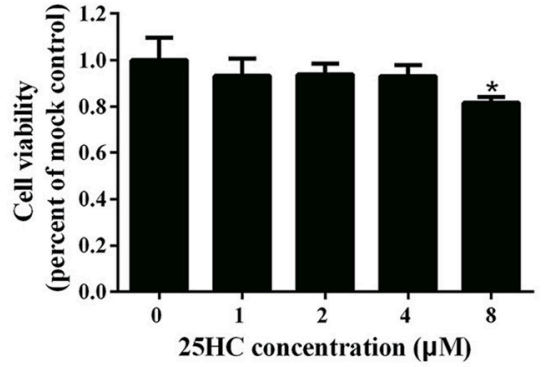

B

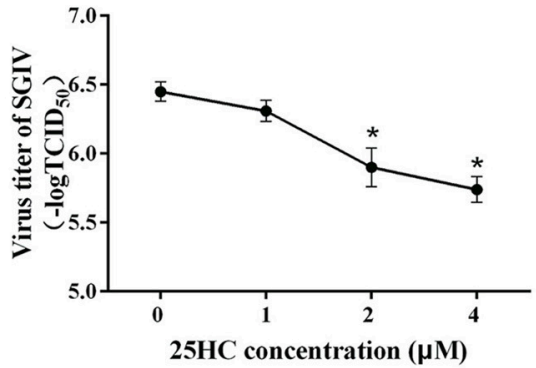

C
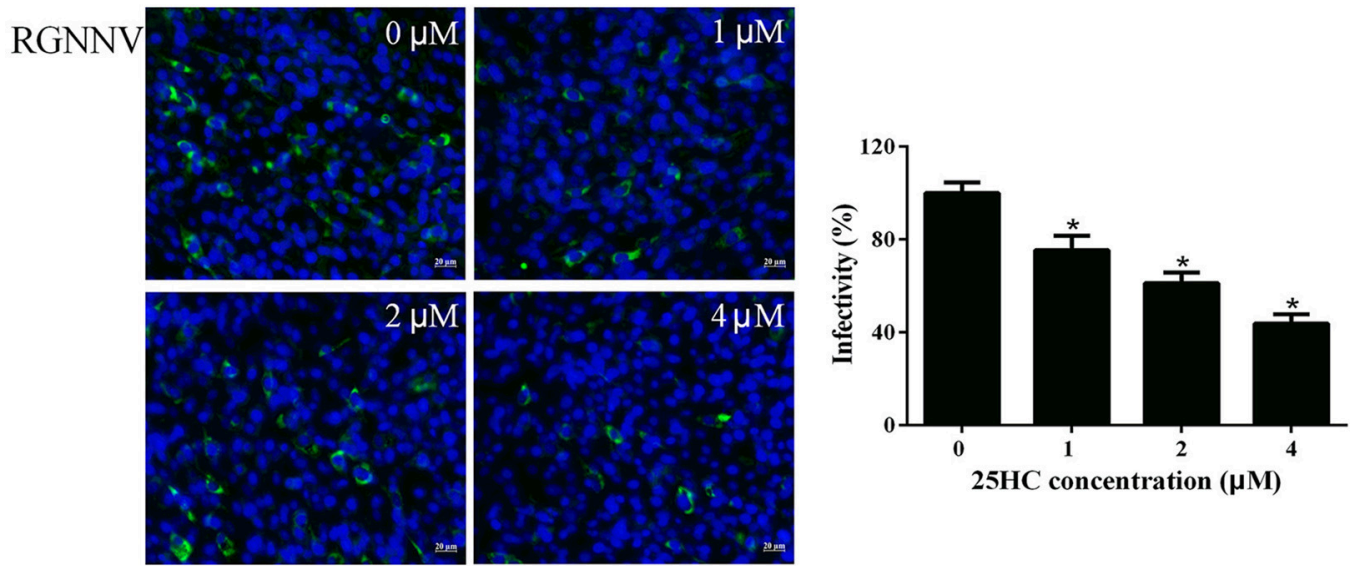

D
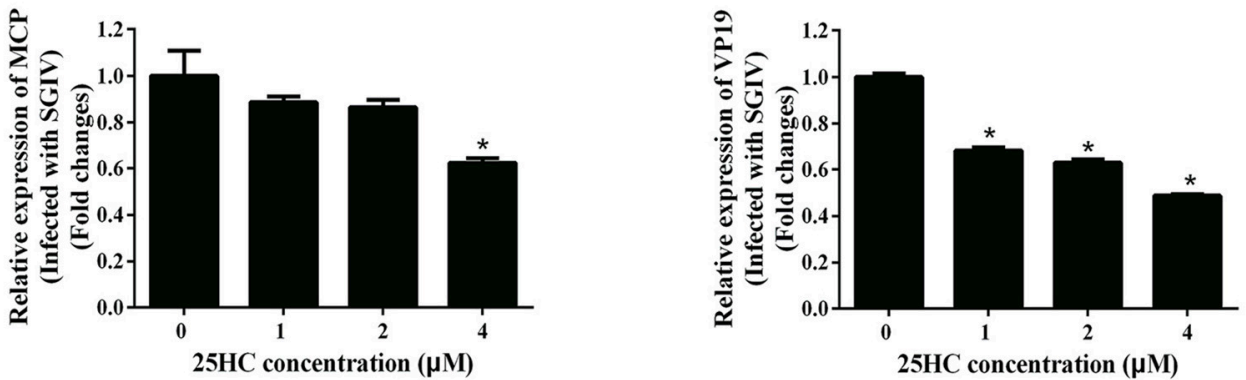

E
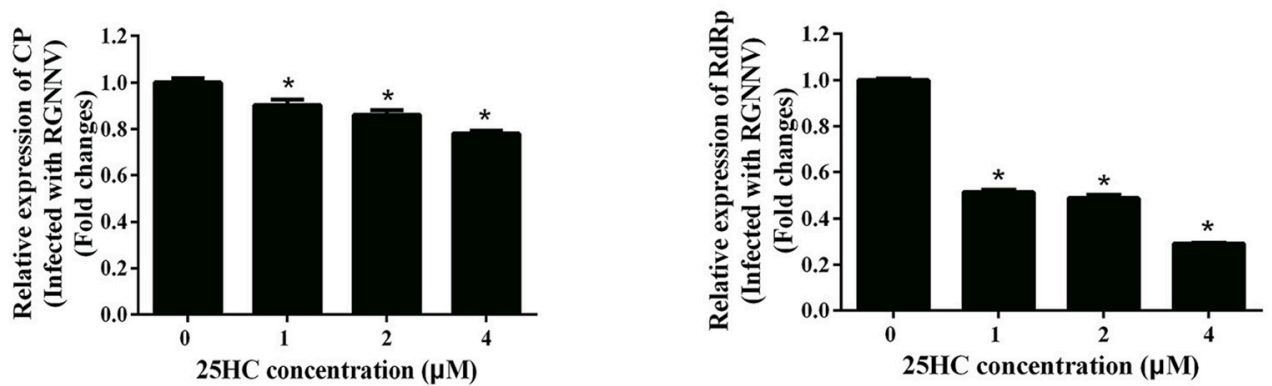

FIGURE 6 | 25HC inhibited SGIV and RGNNV replication in vitro. (A) Cell viability assay. GS cells were pretreated with chloroform (control) or 25HC at 1, 2, 4, or 8 4M. At $72 \mathrm{~h}$ post-treatment, cell viability was determined using an MTT assay. (B-E) $25 \mathrm{HC}$ inhibited SGIV and RGNNV infection. GS cells were pretreated with various concentrations of $25 \mathrm{HC}$ or chloroform for $12 \mathrm{~h}$ prior to SGIV or RGNNV infection, then the infected cells were analyzed at $24 \mathrm{~h}$ p.i. by immunofluorescence assay (IFA) using anti-CP antibody (green). The infectivity was quantified as the percentage of treated cells with incorporated viruses relative to that for control cells. The viral infectivity of control cells was set as $100 \%$ (C). Meanwhile, GS cells were harvested for TCID50 assay of SGIV (B) and qPCR for expression of SGIV (D) or RGNNV (E) genes at 24 h.p.i. $\left(n=3\right.$, means \pm SD). ${ }^{*} P<0.05$. 
A

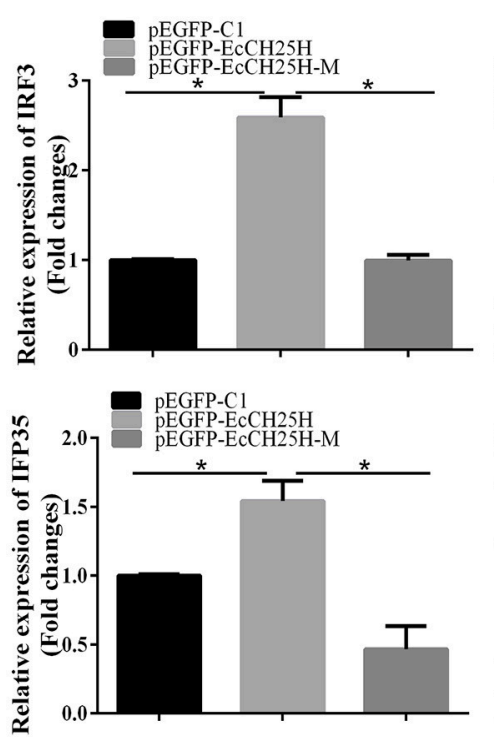

B

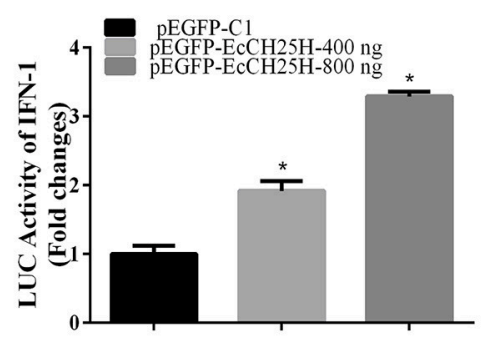

C

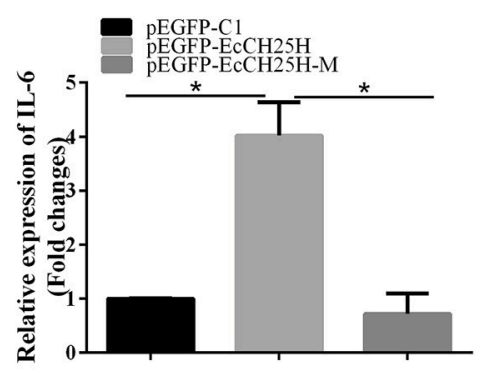

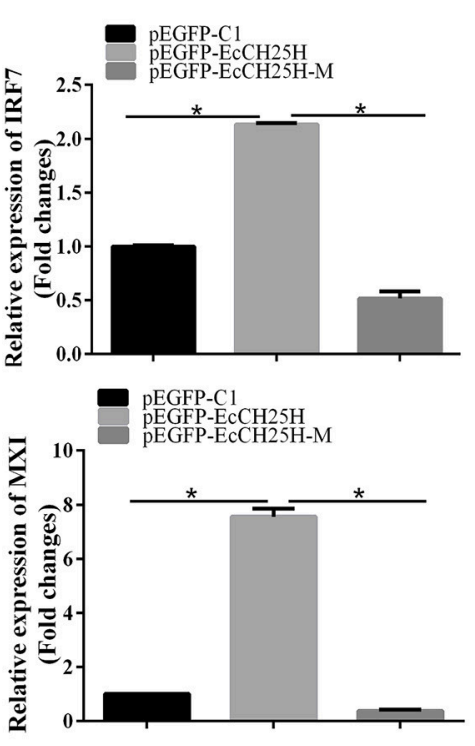
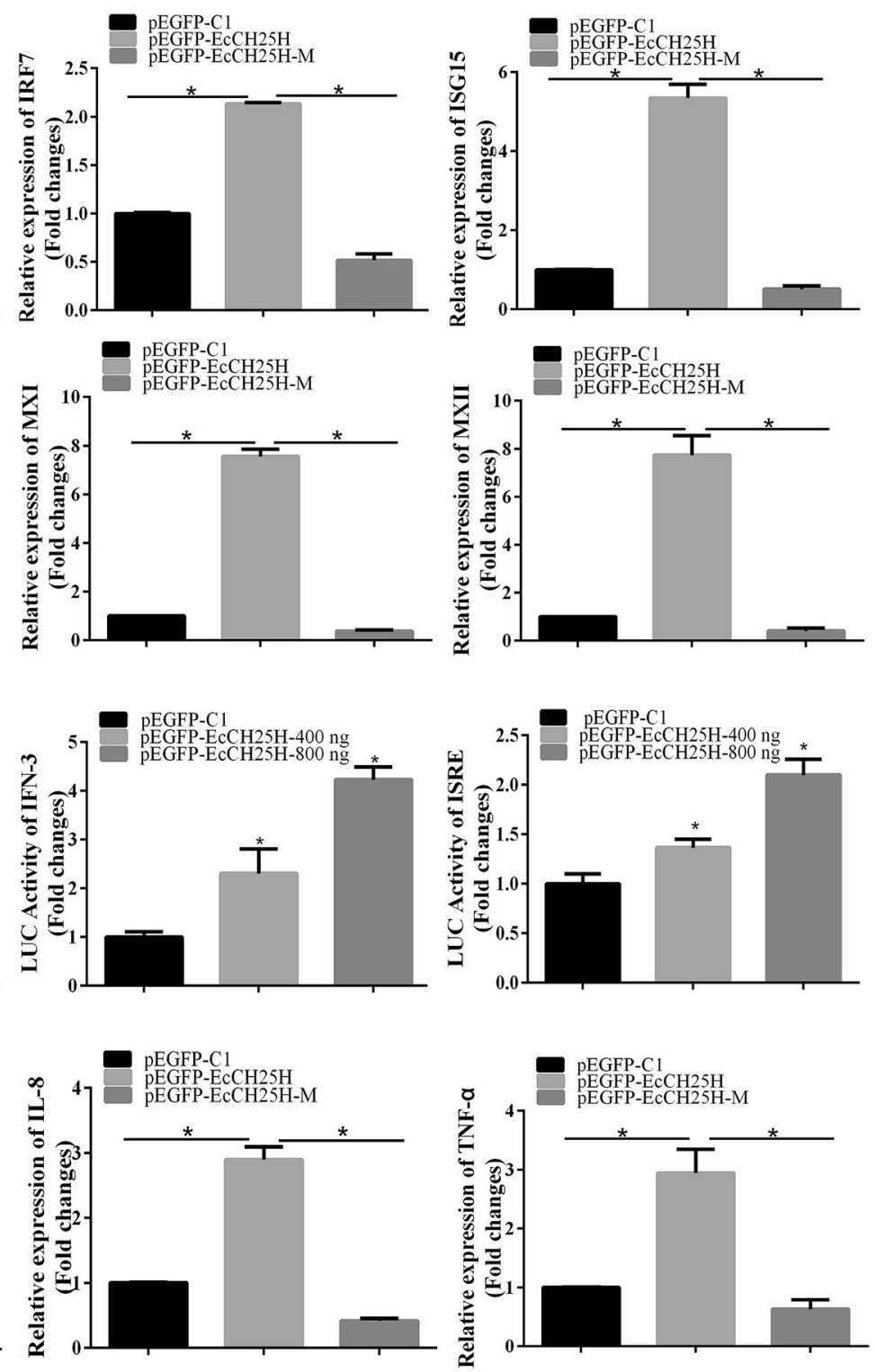

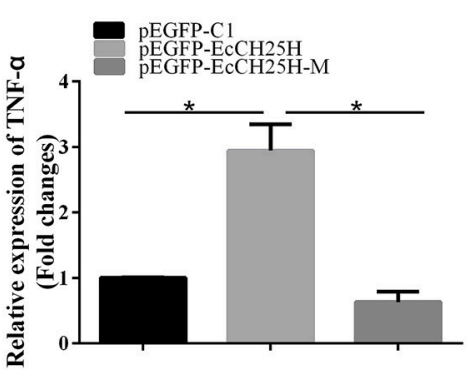

FIGURE 7 | Overexpression of EcCH25H positively regulated IFN and inflammatory response. GS cells were transfected with pEGFP-EcCH25H or pEGFP-EcCH25H-M, and were collected at $48 \mathrm{~h}$ to detect the expression of IFN related signaling molecules (A) including IRF3, IRF7, ISG15, IFP35, MXI, MXII, and proinflammatory factors (C) including IL-6, IL-8, and TNF- $\alpha$ in pEGFP-EcCH25H-, pEGFP-EcCH25H-M-or pEGFP-C1-overexpressing cells by qPCR. Besides, GS cells were co-transfected with ISRE-Luc, IFN1-Luc, IFN3-Luc, and pEGFP-EcCH25H for 48 h, respectively, and cells were harvested to measure the luciferase activities of IFN-1, IFN-3, and ISRE promoter induced by EcCH25H using reporter gene assay (B) $\left(n=3\right.$, means \pm SD). ${ }^{*} P<0.05$.

Zika virus (39), HCV (17), and MCMV (43). In addition, studies had demonstrated that $\mathrm{CH} 25 \mathrm{H}$ could be induced by poly (I:C) (17) and LPS $(44,45)$, which was similar to the results of the present study, suggesting that $\mathrm{CH} 25 \mathrm{H}$ is induced by PAMPs and plays a crucial role in the innate immune response against virus infection. In addition, subcellular localization analysis has shown that $\mathrm{EcCH} 25 \mathrm{H}$ and the catalytically inactive mutant $\mathrm{EcCH} 25 \mathrm{H}-\mathrm{M}$ are both localized in the cytoplasm and have diffuse intracellular expression patterns, which are the same as the localization pattern of pig $\mathrm{CH} 25 \mathrm{H}$ in vitro (21).
As mentioned above, the broad antiviral effects of $\mathrm{CH} 25 \mathrm{H}$ have been demonstrated in mammalian cells for some viruses, and these studies have indicated that $\mathrm{CH} 25 \mathrm{H}$ exerts an antiviral function by production of $25 \mathrm{HC}(39,46)$. It is suggested that $25 \mathrm{HC}$ directly inhibits virus replication by suppressing viral gene expression $(19,43)$. In our study, ectopic expression of $\mathrm{EcCH} 25 \mathrm{H}$ significantly weakened the severity of CPE induced by SGIV and RGNNV infection. Consistently, transcription of viral genes was inhibited by $\mathrm{EcCH} 25 \mathrm{H}$ overexpression and by treatment with $25 \mathrm{HC}$, but was 


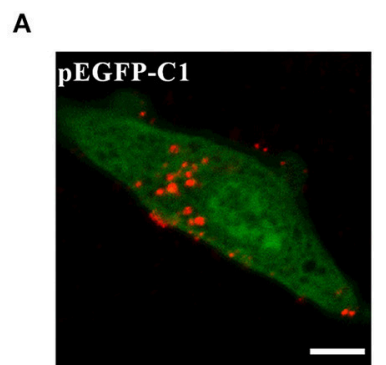

C

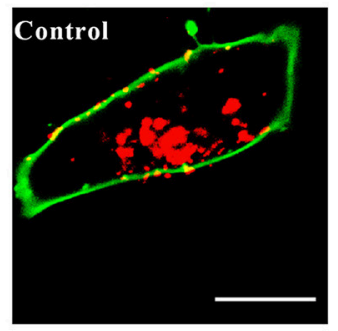

E

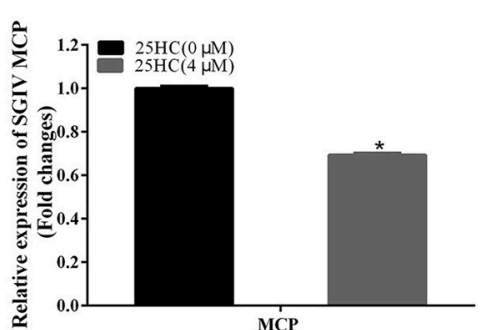

B
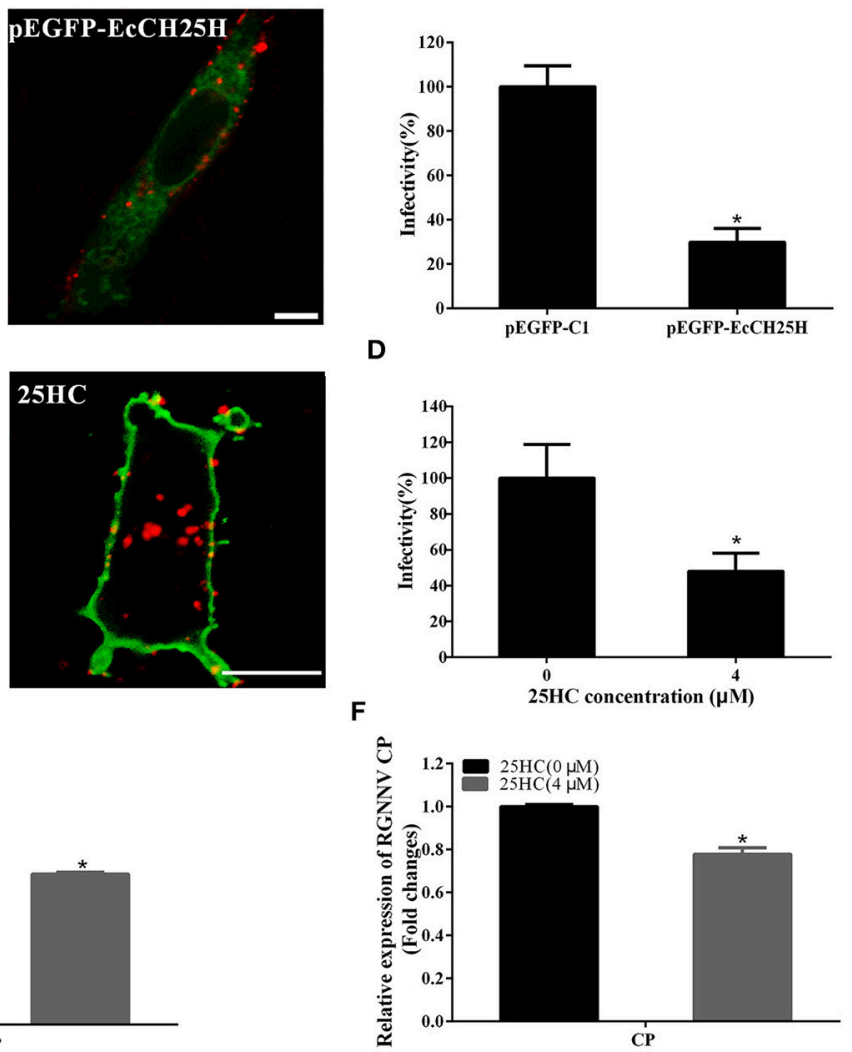

FIGURE 8 | EcCH25H inhibited SGIV and RGNNV entry. (A) EcCH25H-overexpression inhibited SGIV uptake. GS cells were transfected with pEGFP-EcCH25H or pEGFP-C1 for $24 \mathrm{~h}$, followed by infection with Cy5-labeled SGIV (red) for $1 \mathrm{~h}$, and the cells were examined by CLSM. (B) EcCH25H overexpression decreased SGIV infectivity. (C) $25 \mathrm{HC}$ suppressed SGIV uptake. GS cells were pretreated with $25 \mathrm{HC}$ at $4 \mu \mathrm{M}$ or chloroform (control) for $12 \mathrm{~h}$, then infected with SGIV for $1 \mathrm{~h}$ and labeled with $\mathrm{DiO}$ (green). (D) $25 \mathrm{HC}$ decreased SGIV infectivity. The level of infection of the treated cells was normalized to that of the untreated cells. Scale bars were $20 \mu \mathrm{m}$. The data were represented as the means \pm SEM from three independent experiments $(n=30)$. (E,F) GS cells were pretreated with chloroform or $25 \mathrm{HC}$ at $4 \mu \mathrm{M}$ for $12 \mathrm{~h}$, followed by SGIV $(\mathrm{MOI}=8)$ or RGNNV $(\mathrm{MOI}=8)$ infection. The relative expression of SGIV $(\mathbf{E})$ or RGNNV (F) genes were quantified by qPCR $(n=3$, means \pm $\mathrm{SD}) .{ }^{\star} P<0.05$.

enhanced by silencing $\mathrm{EcCH} 25 \mathrm{H}$. In other words, $\mathrm{EcCH} 25 \mathrm{H}$ and $25 \mathrm{HC}$ suppressed viral gene expression to inhibit infection of SGIV and RGNNV.

In addition, recent studies have shown that $\mathrm{CH} 25 \mathrm{H}-\mathrm{M}$ lacking enzymatic activity to produce $25 \mathrm{HC}$ still had antiviral activity against HCV (19) and PRRSV (18), but not against other viruses, such as mouse hepatitis virus 68 and PRV (21), suggesting that $\mathrm{CH} 25 \mathrm{H}$ can inhibit viral infection through either enzyme-activity-dependent or -independent pathways. In this study, we found that $\mathrm{EcCH} 25 \mathrm{H}-\mathrm{M}$ was unable to inhibit replication of SGIV and RGNNV, confirming that the antiviral mechanism of EcCH25H against SGIV and RGNNV is dependent on its enzyme activity and similar to that against other viruses, such as HCV (19) and PRRSV (18). Unexpectedly, the EcCH25H-M showed no effect on SGIV, but enhanced RGNNV replication moderately, indicating that the enhancement of virus replication by $\mathrm{EcCH} 25 \mathrm{H}-\mathrm{M}$ might be dependent on virus type.
Moreover, as a naturally occurring secreted oxysterol, $25 \mathrm{HC}$ can block the fusion of the enveloped viruses with cell membranes to inhibit viral entry (47). For example, $25 \mathrm{HC}$ can modify cell membranes to inhibit efficient fusion between HIV and cell membranes, without affecting HIV transcription, translation and budding (19). 25HC inhibits VSV entry, by a route which is independent of regulation of SREBP2, mevalonate production, or protein prenylation (19). In addition, 25HC inhibits HCV infection at a postentry stage by suppressing activation of SREBP2 (17). Our results show that $\mathrm{EcCH} 25 \mathrm{H}$ overexpression and $25 \mathrm{HC}$ treatment inhibit SGIV entry, in agreement with previous observation for VSV (19). As an enveloped virus, SGIV entered host cells by fusion with the plasma membrane, and $\mathrm{EcCH} 25 \mathrm{H}$ might inhibit SGIV entry by blocking the fusion of viral envelope with cell membranes. Differently, as a non-enveloped virus, RGNNV entry might be affected by the action of EcCH25H on interferon immune response. The detailed mechanism by 
which EcCH25H suppresses SGIV or RGNNV entry needed further investigation.

A growing number of studies have revealed that $\mathrm{CH} 25 \mathrm{H}$ is involved in IFN immune response in few mammals $(17,21,24)$. $25 \mathrm{HC}$ promotes the secretion of some inflammatory cytokines, such as IL-6, IL-8, and macrophage colony-stimulating factor in macrophages and epithelial cells $(48,49)$. To clarify the effects of $\mathrm{EcCH} 25 \mathrm{H}$ on host IFN and inflammatory response, we examined the expression of IFN signaling molecules and proinflammatory cytokines in $\mathrm{EcCH} 25 \mathrm{H}$ - and $\mathrm{EcCH} 25 \mathrm{H}-\mathrm{M}$-overexpressing cells. Expression levels of several IFN-related cytokines, including IRF3, IRF7, ISG15, IFP35, MXI, and MXII, as well as that of inflammatory cytokines, such as TNF- $\alpha$, IL-6, and IL-8, were all significantly increased. Further analysis showed that $\mathrm{EcCH} 25 \mathrm{H}$-overexpression enhanced IFN and ISRE promoter activities. Thus, we speculate that $\mathrm{EcCH} 25 \mathrm{H}$ positively regulates IFN immune and proinflammatory response to inhibit SGIV and RGNNV infection.

In summary, we demonstrated the roles of $\mathrm{EcCH} 25 \mathrm{H}$ in RGNNV and SGIV replication and entry. A fish $\mathrm{CH} 25 \mathrm{H}$ homolog from orange-spotted grouper $(\mathrm{EcCH} 25 \mathrm{H})$ was cloned and characterized. EcCH25H encoded a cytoplasmic protein and was induced by RGNNV or SGIV infection, or by treatment with either LPS or poly (I:C). Overexpression of $\mathrm{EcCH} 25 \mathrm{H}$ in

\section{REFERENCES}

1. Rasmussen SB, Reinert LS, Paludan SR. Innate recognition of intracellular pathogens: detection and activation of the first line of defense. Apmis. (2010) 117:323-37. doi: 10.1111/j.1600-0463.2009.02456.x

2. Akira S, Hemmi H. Recognition of pathogen-associated molecular patterns by TLR family. Immunol Lett. (2003) 85:85-95. doi: 10.1016/S0165-2478(02)00228-6

3. Takeuchi O, Akira S. Pattern recognition receptors and inflammation. Cell. (2010) 140:805-20. doi: 10.1016/j.cell.2010.01.022

4. Schoggins JW, Rice CM. Interferon-stimulated genes and their antiviral effector functions. Curr Opin Virol. (2011) 1:519-25. doi: 10.1016/j.coviro.2011.10.008

5. Aminibavilolyaee S, Choi YJ, Lee JH, Shi M, Huang IC, Farzan M, et al. The antiviral effector IFITM3 disrupts intracellular cholesterol homeostasis to block viral entry. Cell Host Microbe. (2013) 13:452-64. doi: 10.1016/j.chom.2013.03.006

6. Wrensch F, Karsten CB, Gnirß K, Hoffmann M, Lu K, Takada A, et al. Interferon-induced transmembrane protein-mediated inhibition of host cell entry of Ebola viruses. J Infect Dis. (2015) 212 (Suppl._2):S210-8. doi: 10.1093/infdis/jiv255

7. García MA, Meurs EF, Esteban M. The dsRNA protein kinase PKR: virus and cell control. Biochimie. (2007) 89:799-811. doi: 10.1016/j.biochi.2007.03.001

8. Wang X, Hinson ER, Cresswell P. The interferon-inducible protein viperin inhibits influenza virus release by perturbing lipid rafts. Cell Host Microbe. (2007) 2:96-105. doi: 10.1016/j.chom.2007.06.009

9. Neil SJD. The antiviral activities of tetherin. Curr Top Microbiol Immunol. (2013) 371:67-104. doi: 10.1007/978-3-642-37765-5_3

10. Park K, Scott AL. Cholesterol 25-hydroxylase production by dendritic cells and macrophages is regulated by type I interferons. J Leukoc Biol. (2010) 88:1081-7. doi: 10.1189/jlb.0610318

11. Zou T, Garifulin O, Berland R, Boyartchuk VL. Listeria monocytogenes infection induces prosurvival metabolic signaling in macrophages. Infect Immun. (2011) 79:1526. doi: 10.1128/IAI.01195-10

12. Kandutsch AA, Chen HW, Heiniger HJ. Biological activity of some oxygenated sterols. Science. (1978) 201:498-501. doi: 10.1126/science.663671 vitro significantly suppressed replication of SGIV and RGNNV due to its positive effect on the host IFN immune response, which is contrary to the results of RNAi. Furthermore, our results indicate that $\mathrm{EcCH} 25 \mathrm{H}$ inhibits SGIV and RGNNV entry, and shed more light on the mode-of-action of $\mathrm{CH} 25 \mathrm{H}$ against fish virus infection.

\section{AUTHOR CONTRIBUTIONS}

YZ performed the experiments, analyzed the data, and wrote the manuscript. LW and XH prepared virus stocks including SGIV, RGNNV and the purified SGIV. SW participated in confocal microscopy analysis. YH and QQ participated in the design of the study, data analysis and revised the manuscript.

\section{FUNDING}

This work was supported by grants from the National Key Research and Development Program of China (2018YFD0900505), the National Natural Science Foundation of China (31472309, 31772877), National Key R\&D Program of China (2017YFC1404504), and Open Fund of Key Laboratory of Experimental Marine Biology, Chinese Academy of Sciences (No. KF2017NO5).

13. Cyster JG, Dang EV, Reboldi A, Yi, T. 25-Hydroxycholesterols in innate and adaptive immunity. Nat Rev Immunol. (2014) 14:731-43. doi: 10.1038/ nri3755

14. Kandutsch AA, Chen HW. Inhibition of sterol synthesis in cultured mouse cells by cholesterol derivatives oxygenated in the side chain. J Biol Chem. (1974) 249:6057-61.

15. Janowski BA, Grogan MJ, Jones SA, Wisely GB, Kliewer SA, Corey EJ, et al. Structural requirements of ligands for the oxysterol liver X receptors LXR $\alpha$ and LXR $\beta$. Proc Natl Acad Sci USA. (1999) 96:266-71. doi: 10.1073/pnas.96.1.266

16. Chen Y, Wang S, Yi Z, Tian H, Aliyari R, Li Y, et al. Interferoninducible cholesterol-25-hydroxylase inhibits hepatitis $\mathrm{C}$ virus replication via distinct mechanisms. Sci Rep. (2014) 4:7242. doi: 10.1038/srep 07242

17. Xiang Y, Tang JJ, Tao W, Cao X, Song BL, Zhong J. Identification of cholesterol 25-hydroxylase as a novel host restriction factor and a part of the primary innate immune responses against hepatitis C virus infection. J Virol. (2015) 89:6805-16. doi: 10.1128/JVI.00587-15

18. Ke W, Fang L, Jing H, Tao R, Wang T, Li Y, et al. Cholesterol 25-hydroxylase inhibits porcine reproductive and respiratory syndrome virus replication through enzyme activity dependent and independent mechanisms. J Virol. (2017) 91:e00827-17. doi: 10.1128/JVI.00827-17

19. Liu SY, Aliyari R, Chikere K, Li G, Marsden MD, Smith JK, et al. Interferon-inducible cholesterol-25-hydroxylase broadly inhibits viral entry by production of 25-hydroxycholesterol. Immunity. (2013) 38:92-105. doi: 10.1016/j.immuni.2012.11.005

20. Mackenzie JM, Khromykh AA, Parton RG. Cholesterol manipulation by West Nile virus perturbs the cellular immune response. Cell Host Microbe. (2007) 2:229-39. doi: 10.1016/j.chom.2007.09.003

21. Wang J, Zeng L, Zhang L, Guo ZZ, Lu SF, Ming SL, et al. Cholesterol 25 hydroxylase acts as a host restriction factor on pseudorabies virus replication. J Gen Virol. (2017) 98:1467-76. doi: 10.1099/jgv.0.000797

22. Cagno V, Civra A, Rossin D, Calfapietra S, Caccia C, Leoni V, et al. Inhibition of herpes simplex-1 virus replication by 25hydroxycholesterol and 27-hydroxycholesterol. Redox Biol. (2017) 12(C):522-7. doi: 10.1016/j.redox.2017.03.016 
23. Arita M, Kojima H, Nagano T, Okabe T, Wakita T, Shimizu H. Oxysterolbinding protein family $\mathrm{I}$ is the target of minor enviroxime-like compounds. J Virol. (2013) 87:4252-60. doi: 10.1128/JVI.03546-12

24. Song Z, Zhang Q, Liu X, Bai J, Zhao Y, Wang X, et al. Cholesterol 25hydroxylase is an interferon-inducible factor that protects against porcine reproductive and respiratory syndrome virus infection. Vet Microbiol. (2017) 210:153. doi: 10.1016/j.vetmic.2017.09.011

25. Ling L, Zhou SY, Chen C, Weng SP, Chan SM, He JG. Complete genome sequence analysis of an iridovirus isolated from the orangespotted grouper, Epinephelus coioides. Virology. (2005) 339:81-100. doi: 10.1016/j.virol.2005.05.021

26. Qin QW, Chang SF, Ngoh-Lim GH, Gibson-Kueh S, Shi C, Lam TJ. Characterization of a novel ranavirus isolated from grouper Epinephelus tauvina. Dis Aquat Organ. (2003) 53:1-9. doi: 10.3354/dao053001

27. Huang X, Huang Y, Xu L, Wei S, Ouyang Z, Feng J, et al. Identification and characterization of a novel lymphocystis disease virus isolate from cultured grouper in China. J Fish Dis. (2015) 38:379-87. doi: 10.1111/jfd.12244

28. Qin QW, Lam TJ, Sin YM, Shen H, Chang SF, Ngoh GH, et al. Electron microscopic observations of a marine fish iridovirus isolated from brownspotted grouper, Epinephelus tauvina. J Virol Methods. (2001) 98:17-24. doi: 10.1016/S0166-0934(01)00350-0

29. Wen JS, Qi WQ, Jin Q, Huang CH, Fan W, Hew CL. Functional genomics analysis of Singapore grouper iridovirus: complete sequence determination and proteomic analysis. J Virol. (2004) 78:12576. doi: 10.1128/JVI.78.22.12576-12590.2004

30. Mori KI, Nakai T, Muroga K, Arimoto M, Mushiake K, Furusawa I. Properties of a new virus belonging to nodaviridae found in larval striped jack (Pseudocaranx dentex) with nervous necrosis. Virology. (1992) 187:368-71. doi: 10.1016/0042-6822(92)90329-N

31. Iwamoto $\mathrm{T}$, Mise K, Takeda A, Okinaka Y, Mori KI, Arimoto M, et al. Characterization of striped jack nervous necrosis virus subgenomic RNA3 and biological activities of its encoded protein B2. J Gen Virol. (2005) 86(Pt 10):2807-16. doi: 10.1099/vir.0.80902-0

32. Huang X, Huang Y, Cai J, Wei S, Ouyang Z, Qin Q. Molecular cloning, expression and functional analysis of ISG15 in orange-spotted grouper, Epinephelus coioides. Fish Shellfish Immunol. (2013) 34:1094-102. doi: 10.1016/j.fsi.2013.01.010

33. Huang Y, Zhang J, Ouyang Z, Liu J, Zhang Y, Hu Y, et al. Grouper MAVS functions as a crucial antiviral molecule against nervous necrosis virus infection. Fish Shellfish Immunol. (2018) 72:14-22. doi: 10.1016/j.fsi.2017.10.035

34. Huang Y, Huang X, Cai J, Ouyang Z, Wei S, Wei J, et al. Identification of orange-spotted grouper (Epinephelus coioides) interferon regulatory factor 3 involved in antiviral immune response against fish RNA virus. Fish Shellfish Immunol. (2015) 42:345-52. doi: 10.1016/j.fsi.2014.11.025

35. Huang Y, Huang X, Yang Y, Jia C, Ouyang Z, Cui H, et al. Transcriptome analysis of orange-spotted grouper (Epinephelus coioides) spleen in response to Singapore grouper iridovirus. BMC Genomics. (2011) 12:556. doi: 10.1186/1471-2164-12-556

36. Labella AM, Garcia-Rosado E, Bandín I, Dopazo CP, Castro D, Alonso MC, et al. Transcriptomic profiles of senegalese sole infected with nervous necrosis virus reassortants presenting different degree of virulence. Front Immunol. (2018) 9:1626. doi: 10.3389/fimmu.2018.01626

37. Huang X, Huang Y, Sun J, Han X, Qin Q. Characterization of two grouper Epinephelus akaara cell lines: application to studies of Singapore grouper iridovirus (SGIV) propagation and virus-host interaction. Aquaculture. (2009) 292:172-9. doi: 10.1016/j.aquaculture.2009.04.019
38. Wang S, Huang X, Huang Y, Hao X, Xu H, Cai M, et al. Entry of a novel marine DNA virus, Singapore grouper iridovirus, into host cells occurs via clathrinmediated endocytosis and macropinocytosis in a $\mathrm{pH}$-dependent manner. $J$ Virol. (2014) 88:13047-63. doi: 10.1128/JVI.01744-14

39. Li C, Deng YQ, Wang S, Ma F, Aliyari R, Huang XY, et al. 25Hydroxycholesterol protects host against Zika virus infection and its associated microcephaly in a mouse model. Immunity. (2017) 46:446. doi: 10.1016/j.immuni.2017.02.012

40. Lund EG, Kerr TA, Sakai J, Li WP, Russell DW. cDNA cloning of mouse and human cholesterol 25-hydroxylases, polytopic membrane proteins that synthesize a potent oxysterol regulator of lipid metabolism. J Biol Chem. (1998) 273:34316. doi: 10.1074/jbc.273.51.34316

41. Anggakusuma, Romerobrey I, Berger C, Colpitts CC, Boldanova T, Engelmann M, et al. Interferon-inducible cholesterol-25-hydroxylase restricts hepatitis $\mathrm{C}$ virus replication through blockage of membranous web formation. Hepatology. (2015) 62:702-14. doi: 10.1002/hep.27913

42. Pereiro P, Forncuní G, Dios S, Coll J, Figueras A, Novoa B. Interferonindependent antiviral activity of 25-hydroxycholesterol in a teleost fish. Antivir Res. (2017) 145:146. doi: 10.1016/j.antiviral.2017.08.003

43. Blanc M, Hsieh WY, Robertson KA, Kropp KA, Forster T, Shui G, et al. The transcription factor STAT-1 couples macrophage synthesis of 25hydroxycholesterol to the interferon antiviral response. JAK-STAT. (2013) 38:106-18. doi: 10.1016/j.immuni.2012.11.004

44. Preuss I, Ludwig MG, Baumgarten B, Bassilana F, Gessier F, Seuwen K, et al. Transcriptional regulation and functional characterization of the oxysterol/EBI2 system in primary human macrophages. Biochem Biophys Res Commun. (2014) 446:663-8. doi: 10.1016/j.bbrc.2014.01.069

45. Dang EV, Mcdonald JG, Russell DW, Cyster JG. Oxysterol restraint of cholesterol synthesis prevents AIM2 inflammasome activation. Cell. (2017) 171:1057-71. doi: 10.1016/j.cell.2017.09.029

46. Civra A, Cagno V, Donalisio M, Biasi F, Leonarduzzi G, Poli G, et al. Inhibition of pathogenic non-enveloped viruses by 25-hydroxycholesterol and 27-hydroxycholesterol. Sci Rep. (2014) 4:7487. doi: 10.1038/ srep07487

47. Lembo D, Cagno V, Civra A, Poli G. Oxysterols: an emerging class of broad spectrum antiviral effectors. Mol Aspects Med. (2016) 49:23-30. doi: 10.1016/j.mam.2016.04.003

48. Koarai A, Yanagisawa S, Sugiura H, Ichikawa T, Kikuchi T, Furukawa $\mathrm{K}$, et al. 25-Hydroxycholesterol enhances cytokine release and toll-like receptor 3 response in airway epithelial cells. Respir Res. (2012) 13:63. doi: 10.1186/1465-9921-13-63

49. Gold ES, Diercks AH, Podolsky I, Podyminogin RL, Askovich PS, Treuting PM, et al. 25-Hydroxycholesterol acts as an amplifier of inflammatory signaling. Proc Natl Acad Sci USA. (2014) 111:10666-71. doi: $10.1073 /$ pnas.1404271111

Conflict of Interest Statement: The authors declare that the research was conducted in the absence of any commercial or financial relationships that could be construed as a potential conflict of interest.

Copyright (c) 2019 Zhang, Wang, Huang, Wang, Huang and Qin. This is an openaccess article distributed under the terms of the Creative Commons Attribution License (CC BY). The use, distribution or reproduction in other forums is permitted, provided the original author(s) and the copyright owner(s) are credited and that the original publication in this journal is cited, in accordance with accepted academic practice. No use, distribution or reproduction is permitted which does not comply with these terms. 